\title{
Optically stimulated luminescence and isothermal thermoluminescence dating of high sensitivity and well bleached quartz from Brazilian sediments: from Late Holocene to beyond the Quaternary?
}

\author{
Datação de sedimentos brasileiros por luminescência \\ opticamente estimulada e termoluminescência isotérmica \\ do quartzo: do Holoceno tardio ao Plioceno?
}

\author{
André Oliveira Sawakuchi ${ }^{1 *}$, Vinicius Ribau Mendes ${ }^{1}$, Fabiano do Nascimento \\ Pupim $^{1}$, Thays Desiree Mineli ${ }^{1}$, Ligia Maria Almeida Leite Ribeiro ${ }^{2}$, Andre Zular ${ }^{1}$, \\ Carlos Conforti Ferreira Guedes ${ }^{3}$, Paulo César Fonseca Giannini ${ }^{1}$, Luciana Nogueira ${ }^{1}$, \\ William Sallun Filho ${ }^{4}$, Mario Luis Assine ${ }^{5}$
}

\begin{abstract}
The development of optically stimulated luminescence (OSL) dating of sediments has led to considerable advance in the geochronology of the Quaternary. OSL dating is a well established technique to determine sediment burial ages from tens of years to few hundred thousand years. Recent studies have shown that Quaternary sediments of Brazil are dominated by quartz grains with high luminescence sensitivity, allowing the determination of precise and reliable OSL burial ages. In this paper, we show examples of OSL dating of quartz aliquots and single grains from different regions in Brazil, including young coastal-eolian Late Holocene ( $<100$ years) to Late Pleistocene $(\sim 150 \mathrm{ka})$ fluvial sediments. We discuss the OSL data and ages of sediments from carbonate and terrigenous (distributary and tributary systems) fluvial depositional contexts in Brazil. Most of the studied fluvial sediments show equivalent dose distributions with low to moderate dispersion, suggesting well bleached sediments. The comparison between aliquot and single grain data suggests that high overdispersion in equivalent dose distributions of some samples is more related with sediment mixture due to bioturbation than with incomplete bleaching during transport.
\end{abstract}

\footnotetext{
1'Institute of Geosciences, Universidade de São Paulo - USP, São Paulo (SP), Brazil. E-mail: andreos@usp.br, viniciusr@usp.br,fabianopupim@gmail.com, thaysdesiree@gmail.com, andrezular@gmail.com,pcgianni@usp.br, luciana.mailme@gmail.com

${ }^{2}$ CPRM - Serviço Geológico do Brasil, São Paulo (SP), Brazil. E-mail: ligia.ribeiro@cprm.gov.br

${ }^{3}$ Department of Geology, Universidade Federal do Paraná - UFPR, Curitiba (PR), Brazil. E-mail: ccfguedes@gmail.com

${ }^{4}$ Geological Institute, Governo do Estado de São Paulo, Secretaria do Meio Ambiente, São Paulo (SP), Brazil. E-mail: wsallu@gmail.com

${ }^{5}$ Department of Applied Geology, Institute of Geosciences and Exact Sciences, Universidade Estadual Paulista "Júlio de Mesquita Filho" - UNESP, Rio Claro (SP) Brazil.E-mail: assine@rc.unesp.br

*Corresponding author.

Manuscript ID: 30295. Received in: 05/01/2015. Approved in: 01/18/2016.
} 
Well bleached fluvial sediments contrast with the poor bleached pattern usually described for fluvial sediments in the literature. A large part of the fluvial sedimentary record in Brazil is older than the age limit for quartz OSL dating using blue light stimulation. Thus, isothermal thermoluminescence (ITL) dating protocols were tested for dating of fluvial sands from the Xingu River (eastern Amazonia). The studied sample can recover reliable equivalent doses up to $1600 \mathrm{~Gy}$ using the ITL $310^{\circ} \mathrm{C}$ signal. Therefore, this signal would be suitable to extend the age limit of quartz luminescence to the whole Quaternary or beyond $(>2 \mathrm{Ma})$ in the low dose rate $(0.5-1.0 \mathrm{~Gy} / \mathrm{ka})$ environments typical for Brazilian sediments.

KEYWORDS: OSL dating; Quartz; Quaternary geochronology; Brazilian sediments.

\section{INTRODUCTION}

Luminescence dating of minerals was proposed by Aitken et al. (1964) as a method to determine the firing age of archaeological ceramic materials. Since this benchmark work, many studies aimed to develop protocols for dating the firing age of archaeological materials (ceramics and bricks), formation age of meteorites and burial age of sediments using thermoluminescence (TL) signals. Initial studies using TL dating of sediments commonly were showing age overestimation compared to other independent age controls such as radiocarbon. This was ascribed to the difficulty of measuring an optically reset luminescence signal (in the environment) by a thermoluminescence approach. The introduction of optically stimulated luminescence (OSL) solved that issue (Huntley et al. 1985). OSL became a widely applied method for dating Quaternary terrigenous sediments following the methodological work of Murray and Wintle (2000), by introducing the single-aliquot regenerative dose (SAR) protocol. Nowadays, OSL dating has proven that it is a reliable method to provide deposition ages of terrigenous sediments, from few years up to 100,000 years and beyond, in certain situations. Based on the luminescence of common silicate minerals (e.g. quartz and potassium feldspar), the method is suitable for dating sedimentary deposits containing silicate minerals, which fall outside the applicability range of most dating techniques such as radiocarbon and U-Th series. The OSL dating method has contributed to the progress of various fields of science related to Earth surface changes during the Quaternary. It has enabled significant progress in the past 15 years to understand the link between sedimentation and past variation in climate, relative sea level and tectonic activities.

Luminescence dating is a well established method to determine burial ages of quartz and potassium feldspar from Holocene to Pleistocene sediments (100 ka; Murray \& Wintle 2003, Rhodes 2011, Buylaert et al. 2012). Under favorable conditions, OSL dating proved to be reliable up to the Middle pelo fotoesvaziamento incompleto. Grande parte do registro sedimentar fluvial brasileiro tem idade superior ao limite da datação por OSL para o quartzo. Desse modo, protocolos de datação por termoluminescência isotérmica (isothermal thermoluminescence, ITL) foram testados com objetivo de ampliar o alcance da datação por luminescência. O protocolo de datação ITL foi testado em uma amostra de quartzo do rio Xingu (leste da Amazônia). Foi possivel recuperar doses equivalentes de até $1600 \mathrm{~Gy}$, por meio do sinal ITL $310^{\circ} \mathrm{C}$ do quartzo. Assim, esste sinal mostrou-se adequado para ampliar o limite da datação por luminescência para todo o período Quaternário. Em depósitos sedimentares brasileiros, cujas taxas de dose são relativamente baixas $(0,5-$ 1,0 Gy/ka), seria possivel datar sedimentos até o Plioceno (> $2 \mathrm{Ma}$ ) por meio do sinal ITL310 $\mathrm{C}$.

PALAVRAS-CHAVE: Datação OSL; Quartzo; Quaternário, geocronologia; Sedimentos brasileiros.

Pleistocene $(-300-400 \mathrm{ka})$. Recent studies have attempted to extend the age limit of luminescence dating (Wang et al. 2006, Jain et al. 2005, 2007, Vandenberghe et al. 2009, Duller et al. 2012). A lot of work is still needed to confirm the validity of these novel methodological approaches. If any of these are successful, luminescence dating could potentially be applied for the whole Quaternary period.

Quaternary sediments in Brazil are suitable for luminescence dating in the Holocene to Late Pleistocene range, especially due to the widespread occurrence of quartz grains with high OSL light intensity. Quartz from these regions have shown to be dominated by the fast component (Guedes et al. 2013), a highly desirable characteristic for OSL dating. However, there is no information about the suitability of Brazilian sediments for cutting-edge luminescence dating procedures with the potential to determine much older burial ages. In this paper, we present the basic principles of OSL dating, along with examples of OSL dating of Late Holocene to Late Pleistocene sediments from coastal and continental settings in Brazil. Study cases comprise the review of published OSL ages of coastal sediments (Zular et al. 2012) and fluvial carbonate sediments (Ribeiro et al. 2015), as well as new OSL data about fluvial sediments from the Pantanal wetland and Parnaíba River. Finally, we explored the potential of isothermal thermoluminescence (ITL) signals (Jain et al. 2007, Vandenberghe et al. 2009) in dating older Brazilian sediments from the Xingu River (eastern Amazonia).

\section{BASIC PRINCIPLES OF OPTICALLY STIMULATED LUMINESCENCE DATING}

\section{Principles of luminescence dating}

The first description of luminescence (thermoluminescence, TL) phenomena is attributed to Sir Robert Boyle in 
1664, who observed the emission of light from a diamond crystal when held near a candle (Yukihara \& McKeever 2011). However, studies that supported the development of luminescence dating of geological materials were carried out only during the 1960s (Johnson 1963, 1966, Macdiarmid 1963) through the application of thermoluminescence. Dating studies were based on TL until 1985, when the OSL was discovered (Huntley et al. 1985). TL and OSL are the light emitted by materials previously exposed to ionizing radiation, which are then stimulated by heat and light, respectively (Huntley et al. 1985, Yukihara \& McKeever 2011). TL and OSL are present in several minerals such as quartz, feldspar, zircon and calcite (Aitken 1998). As such, these materials act as natural radiation dosimeters as the register the amount of ionizing radiation to which they are exposed to. In extension, synthetic phosphors are used in personal dosimetry (Yukihara \& McKeever 2011).

Luminescence dating measures the time elapsed since minerals such as quartz and feldspar were exposed to sunlight. It requires that these minerals be sufficiently exposed to sunlight during their last sedimentary cycle (erosion, transport and deposition), in order to completely reset (bleach) any latent luminescence signal. After deposition, mineral grains are protected once more from sunlight, and begin to record the ambient natural ionizing radiation. The burial age can be determined from the ratio between the absorbed (natural) radiation dose (equivalent dose, De) and the ambient radiation dose rate (Da) surrounding the sample (Eq. 1).

$$
A g e[k a]=\frac{D e[G y]}{\left(D_{\alpha}+D_{\beta}+D_{\gamma}+D_{C}\right)[G y / k a]}
$$

The equivalent dose (De) is the amount of ionizing radiation energy absorbed in matter per unit mass. The SI unit for a De is the Gray (Gy), $1 \mathrm{~Gy}=1 \mathrm{~J} / \mathrm{kg}$. Natural radiation exposure results from the disintegration of natural radionuclides (mainly ${ }^{40} \mathrm{~K},{ }^{238} \mathrm{U}$ and ${ }^{232} \mathrm{Th}$ ) in the form of alpha $\left(\mathrm{D}_{\alpha}\right)$ and beta $\left(\mathrm{D}_{\beta}\right)$ particles, and gamma rays $\left(\mathrm{D}_{\gamma}\right)$. There is also a contribution from cosmic rays $(\mathrm{D} c)$.

OSL signals are bleached faster than TL signals when minerals grains are exposed to sunlight (Godfrey-Smith et al. 1988). This is a major advantage of OSL over TL for determining the burial ages of Holocene and Late Pleistocene sediments. Although many minerals emit luminescence, well established luminescence dating protocols are based on the estimation of equivalent doses in quartz or potassium feldspar grains, in great part due to the high abundance of quartz and intense luminescence signal of potassium feldspar (Aitken 1998). Luminescence dating is routinely measured from fine sand fractions $(63-250 \mu \mathrm{m})$ of quartz or potassium feldspar, or from polymineral fine silt $(4-11 \mu \mathrm{m})$. Luminescence dating can also be performed on individual grains, typically in the $180-250 \mu \mathrm{m}$ grain size. The OSL from quartz relies on blue light for stimulation while detecting the luminescence response in the ultraviolet (UV) band. Potassium feldspar is usually measured using infrared stimulation (IRSL) with the signal detected in the blue band. Figure 1 shows OSL and IRSL decay curves of quartz and potassium feldspar aliquots, respectively. The dating of potassium feldspar (Rhodes 2011, Buylaert et al. 2012) is an alternative when quartz is shown to be unsuitable due to low OSL sensitivity (Aitken 1998). Also, higher equivalent doses can be measured for potassium feldspar when compared to quartz OSL. However, IRSL signals of potassium feldspar suffer from anomalous fading (Huntley \& Lamothe et al. 2001), i.e. spontaneous signal loss, which leads to age underestimation. Despite the discovery of a relatively stable post-infrared infrared ( $\mathrm{pIRIR}$ ) signals of potassium feldspar, without significant fading (Thomsen et al. 2008, Buylaert et al. 2012), their lower saturation doses, slower bleaching rate, and higher residual doses limit their application. More detailed information about the pIRIR luminescence dating of potassium feldspar can be found in Buylaert et al. (2012). The next sections of this study will focus on the luminescence dating of quartz.

\section{Equivalent dose (De) estimation}

Three main components (fast, medium and slow) have been used to describe the OSL decay curve of quartz (Bailey et al. 1997). The fast component, which dominates the first $0.8-1.0$ s of light emission, is the most suitable signal for dating of quartz due to its high thermal stability (lifetime of $850 \mathrm{Ma}$ at $20^{\circ} \mathrm{C}$, Murray \& Wintle 1998). The fast component is also rapidly bleached by sunlight. It is reduced to less than $1 \%$ of its original level under just $10 \mathrm{~s}$ (Godfrey-Smith et al. 1988). The saturation dose of the fast OSL component commonly occurs between 100 and 200 Gy (Wintle 2008), limiting the dating range of sediments up to about 100 to $250 \mathrm{ka}$, considering average dose rates of $0.8-1.0 \mathrm{~Gy} / \mathrm{ka}$.

The single-aliquot regenerative (SAR) dose protocol is the most successful approach used to measure the equivalent radiation doses in quartz (Wintle \& Murray 2006). The SAR protocol appropriately measure and correct luminescence sensitivity changes occurring due to repeated cycles of thermal, irradiation and illumination treatments performed during all necessary measurements to determine the equivalent dose. A dose-response curve is obtained by measuring the relationship between the luminescence signal and laboratory-induced radiation dose. The equivalent dose is determined by interpolating 
the natural luminescence signal of an aliquot (multiple grains) or single-grain of quartz (Fig. 2) onto the dose-response curve. Table 1 shows the SAR protocol used to estimate equivalent doses in quartz. A heat treatment (step 2) is applied to eliminate thermally unstable components, present following a laboratory-induced dose (step 1) before measuring the luminescence signal (step 3). Measurement steps 4, 5 and 6 correspond to the test dose $(\mathrm{Dt})$, which is a fixed dose that monitor changes in OSL sensitivity, during each cycle. Quartz is very sensitivity to this heat treatment (step 2). The optimum temperature is determined for each sample with the aid of a dose recovery test. With this test, we can assess the accuracy of the measurement protocol. It consists in optically bleaching an aliquot of quartz, giving it a known, laboratory-induced dose (i.e. the given dose) and proceeding with measuring its equivalent dose (i.e. the measured dose; Tab. 1). The test is repeated for different heat treatment (step 2). Typically, we consider the test as successful when the measured-to-given dose ratio lies between 0.9 and 1.1 . Applied doses Di: D1 > D2 > D3 > D4; D5 = 0 Gy, D6 $=\mathrm{D} 1 ; \mathrm{D} 7=\mathrm{D} 6$, with additional IR stimulation before OSL measurements of D7. A series of measurement tests are included in the measurement protocol: recuperation, recycling and feldspar contamination. The recuperation test is performed near the end. The measures the luminescence response for a $\mathrm{Di}=0 \mathrm{~Gy}$ and is expressed as a ratio of the normalized $\mathrm{Lx} / \mathrm{Tx}$ response of the recuperation divided by the $\mathrm{Lx} / \mathrm{Tx}$ of the natural luminescence (typically expressed as $\mathrm{Ln} / \mathrm{Tn}$ ). Intuitively, it should yield zero, but we tolerate up to $5 \%$ of signal. The recycling ratio is calculated by repeating a complete measurement cycle, at the very end, by giving again the same dose delivered in the first cycle (i.e. D1). Intuitively, the both $\mathrm{Lx} / \mathrm{Tx}$ should be equal, but we tolerate up to $10 \%$ deviation. A failure here implies that the test dose improperly monitored the changes in OSL sensitivity. Feldspar contamination is evaluated by comparing two successive measurement cycles, in which the same dose (step 1) is delivered. In the second cycle, an infrared stimulation is applied before the blue stimulation (i.e. between step 2 and 3). Only feldspar is sensitive to infrared stimulation whereas both quartz and feldspar display a luminescence response under blue stimulation. If the aliquot is contaminated by feldspar, the second Lx/Tx ratio will be lower than the previous. A tolerance of $10 \%$ is also observed here. Further detailed about the SAR protocol for quartz can be found in Wintle and Murray (2006).

Table 1. Single-aliquot regenerative dose protocol used to measure the equivalent dose in quartz aliquots or single grains (Murray \& Wintle 2003).

\begin{tabular}{l|c}
\hline Step & Procedure \\
\hline 1 & Give dose, $\mathrm{D}_{\mathrm{i}}$ \\
\hline 2 & Preheat at 160 to $260^{\circ} \mathrm{C}$ for $10 \mathrm{~s}$ \\
\hline 3 & $\begin{array}{c}\text { Optically stimulate with } \\
\text { blue LEDs for } 40 \text { s at } 125^{\circ} \mathrm{C}(\mathrm{Lx})\end{array}$ \\
\hline 4 & Give test dose, $\mathrm{Dt}$ \\
\hline 5 & Heat to $160^{\circ} \mathrm{C}$ \\
\hline 7 & $\begin{array}{r}\text { Optically stimulate with } \\
\text { blue LEDs for } 40 \text { s at } 125^{\circ} \mathrm{C}(\mathrm{Tx})\end{array}$ \\
\hline 8 & Bleach with blue LEDs for 40 s at $280^{\circ} \mathrm{C}$ \\
\hline
\end{tabular}
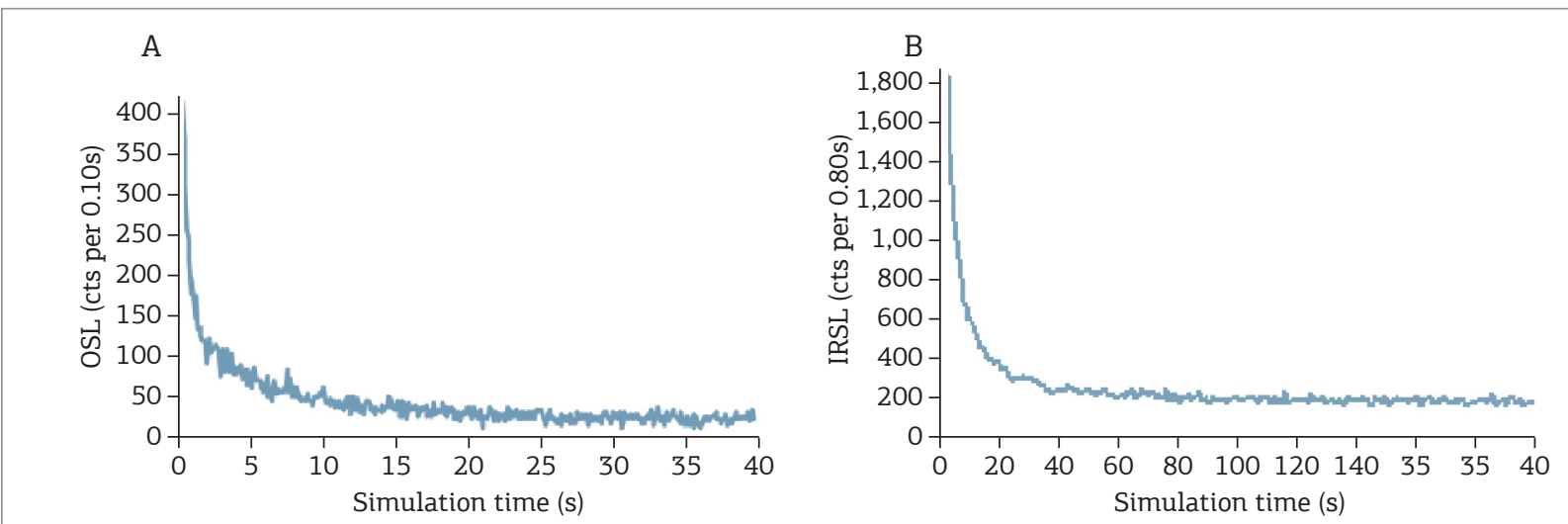

OSL: Optically stimulated luminescence; IRSL: Infrared stimulated luminescence.

Figure 1. Optically stimulated luminescence (A) and infrared stimulation (B) decay curves of quartz (left, blue stimulation) and potassium feldspar, respectively. 


\section{Dose rate estimation}

Natural radionuclides (uranium, U; thorium, Th; and potassium, K) and cosmic rays are the main sources of ionizing radiation contributing to the dosimetric accumulation in buried grains of quartz and potassium feldspar. Alpha and beta particles and gamma rays derived from the decay of natural radionuclides have different travel lengths and linear energy transfer (LET) within sediments. Alpha particles deposit energy only in the outer shell $(10-20 \mu \mathrm{m})$ of a coarse grain $(63-250 \mu \mathrm{m})$. Thus, for quartz, its contribution to the equivalent dose can be eliminated by dissolving the outer shell of the grains with concentrated hydrofluoric acid (HF). However, the alpha contribution must be taken into account for fine grains $(4-11 \mu \mathrm{m})$ or coarse grain feldspar. In this case, the luminescence efficiency of alpha to beta particles must be considered (Mauz et al. 2006). Beta particles and gamma rays have a travel distance within sediments of around $2 \mathrm{~mm}$ and $30 \mathrm{~cm}$, respectively. Thus, beta particles and gamma rays can deposit energy into most of the mineral grains (Aitken 1998). Cosmic rays are attenuated due to their interaction with the Earth magnetic field, atmosphere, surface water and sediments. The dose rate due to cosmic rays is calculated using a mathematical model which takes into account the magnetic latitude, elevation above sea level and sampling depth (Prescott \& Hutton 1994). The presence of water within the sediment attenuates the energy released during the natural disintegration of $\mathrm{U}$, Th and $\mathrm{K}$ that can reach the quartz and feldspar grains. It is a major factor affecting the

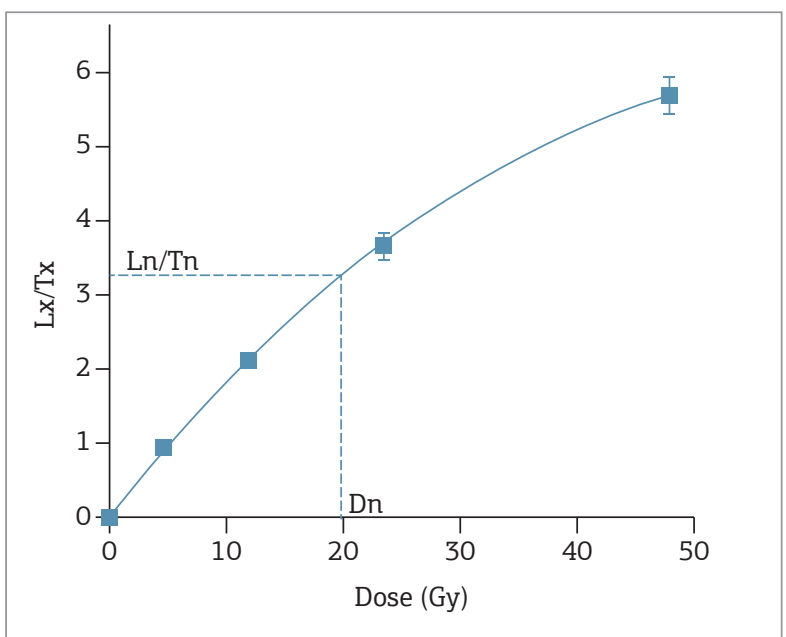

Figure 2. Dose response curve for a quartz aliquot. $\mathrm{Lx} / \mathrm{Tx}$ (step 3/step 6) represents the corrected luminescence signal for a given radiation dose $(\mathrm{Di})$. $\mathrm{Ln} / \mathrm{Tn}$ is the corrected luminescence signal for the natural radiation dose (Dn). The net luminescence signal is calculated by removing the background (last $10 \mathrm{~s}$ of stimulation) from the raw signal (first 1s). radiation LET and dose rate in sediments and must be taken into account for dose rate calculation. The difficulty here is in assessing the "effective" water content that the sample experienced throughout its burial time. A conservative approach is often used here, by assigning a relatively large uncertainty on water content for dose rate calculation.

High resolution gamma rays spectrometry and ICP-MS are often used to determine the abundance (or specific activity) of $U$, Th and $\mathrm{K}$ in sediments. A high resolution gamma spectrometry allows measuring the activities of daughter radionuclides from the $U$ and Th decay series. This is advantageous because it is possible to evaluate the state of equilibrium in the uranium decay series. A loss or uptake of radionuclides, occurring after sediment deposition, negatively affects the dose rate over time, and leads to erroneous luminescence age. This is an issue of concern for dating of carbonate rich (Ribeiro et al. 2015) or heavy weathered sediments. With radionuclides concentrations, we apply conversion factors to obtain a dose rate (Adamiec \& Aitken 1998, Guérin et al. 2011).

\section{OPTICALLY STIMULATED LUMINESCENCE DATING OF BRAZILIAN SEDIMENTS}

\section{Historical background and study cases}

Previous reviews about luminescence dating of Brazilian sediments were presented by Sallun et al. (2007) and Guedes et al. (2013). The last authors presented information regarding the luminescence behavior of the quartz grains found in fluvial, eolian and shallow marine sediments from southeastern and northeastern Brazil and their suitability for equivalent dose estimation using the SAR protocol. Sawakuchi et al. (2011) presented a study of OSL sensitivity of quartz grains extracted from different Brazilian rocks and sediments.

Luminescence dating studies in Brazil can be divided into three groups, which express an evolutionary methodological trend: the pioneer attempts with thermoluminescence in sediments from the Rio Grande do Sul coastal plain (Poupeau et al. 1984, 1988); a second phase of thermoluminescence datings includes the first uses of OSL without the SAR protocol, mainly in coastal and/or eolian contexts (Suguio et al. 1999, 2003, Barreto et al. 2001, 2004, Giannini et al. 2007, 2009, Tatumi et al. 2008) but also in colluvium deposits (Sallun \& Suguio 2010); and, lastly, the application of OSL-SAR to coastal, aeolian and fluvial deposits (Teeuw \& Rhodes 2004, Sawakuchi et al. 2008, Tsoar et al. 2009, Soares et al. 2010, Guedes et al. 2011, Zular et al. 2012, Ribeiro et al. 2015, Mendes et al. 
2015). Sometimes, it was performed in addition to or as validation of ${ }^{14} \mathrm{C}$ dating in archaeological sites, including central Brazil rocky shelters (Araujo et al. 2008, Feathers et al. 2010, Bueno et al. 2012) and Southern Brazil shell-middens (Giannini et al. 2010). This section discusses aspects of OSL dating of quartz from Brazilian sedimentary deposits. OSL dating of quartz from four study settings in Brazil are presented and discussed in the next sections. These settings (Fig. 3) comprise coastal-eolian sediments from southern Brazil, distributary fluvial sediments from the Pantanal wetland in southwestern Brazil, fluvial sediments from the Parnaíba River in northeastern Brazil and carbonate fluvial sediments (tufas) from Serra da Bodoquena and Vale do Ribeira, respectively in southwestern and southeastern Brazil. These study cases comprise sediments from different depositional and physiographical contexts, spanning from tens of years to a few hundred thousand years.

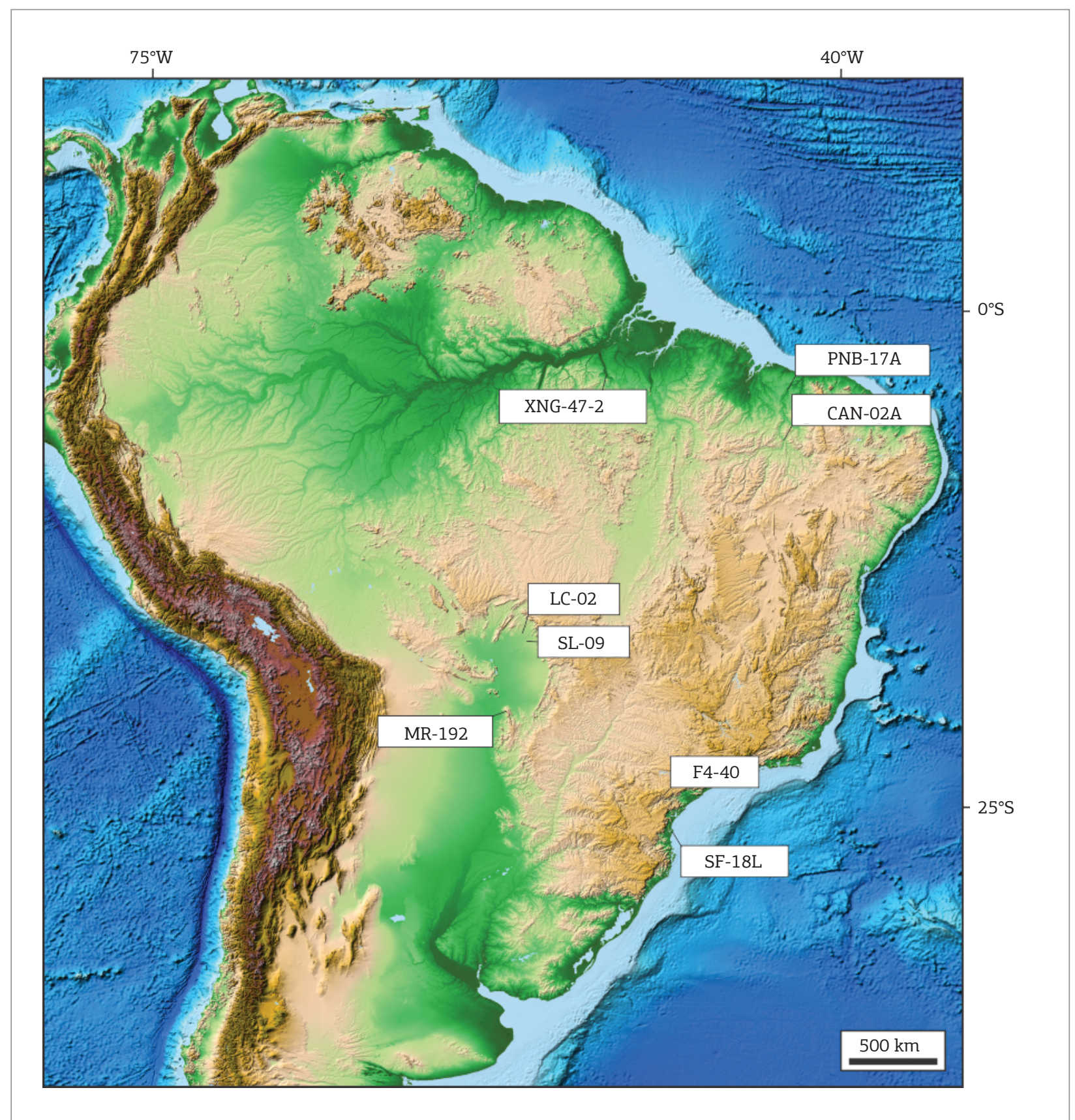

Figure 3. Localization of studied samples. Study cases include samples from the Xingu River (XNG-47-2), Parnaíba River (PNB-17A and CAN-02A), Pantanal wetland (LC-02 and SL-09), Serra da Bodoquena (MR-192), Ribeira Valley (F4-40) and São Francisco do Sul coast (SF-18L). 


\section{Optically stimulated luminescence dating methods}

Samples were collected in opaque PVC or aluminum tubes. Sample preparation followed standard procedures as described in Aitken (1998). Samples were wet sieved to isolate the $180-250$ or $150-180 \mu \mathrm{m}$ grain sizes. Samples of fluvial carbonates (section 3.5) were crushed and etched with hydrochloric acid ( $\mathrm{HCl} \mathrm{10 \% )} \mathrm{to} \mathrm{completely} \mathrm{dissociate}$ individual silicate minerals before wet sieving (Ribeiro et al. 2015). Detailed description of sample preparation of fluvial carbonates is found in Ribeiro et al. (2015). Quartz concentrates were prepared through the treatment with hydrogen peroxide $\left(\mathrm{H}_{2} \mathrm{O}_{2} 27 \%\right)$ and $\mathrm{HCl} 10 \%$ in order to eliminate organic matter and carbonates, respectively. HF 40\% was used to dissolve the outer shell of quartz grains, which is exposed to external alpha particles, and to remove other minerals. Remnant feldspar and heavy minerals were separated from quartz grains through heavy liquid separation using lithium metatungstate solution at densities of 2.85 and $2.62 \mathrm{~g} / \mathrm{cm}^{3}$. All OSL measurements were carried out in the $2.62-2.85 \mathrm{~g} / \mathrm{cm}^{3}$ density fraction.

Luminescence measurements were carried out with two Risø TL/OSL DA-20 readers from the Luminescence and Gamma Spectrometry Laboratory of the Universidade de São Paulo. Both readers are equipped with blue and IR LEDs for stimulation and built-in ${ }^{90} \mathrm{Sr} /{ }^{90} \mathrm{Y}$ beta radiation sources, delivering doses rates of 0.084 and $0.115 \mathrm{~Gy} / \mathrm{s}$. One reader is equipped with a single-grain attachment with green laser for stimulation of single-grains. The SAR protocol (Murray $\&$ Wintle 2003) was used for equivalent dose estimation (Tab. 1). Preheat temperatures used for the studied samples were $200^{\circ} \mathrm{C}$ or $220^{\circ} \mathrm{C}$. Only aliquots or single grains with recycling ratios between 0.9 and 1.1 and recuperation less than $5 \%$ were used for equivalent dose calculation. All aliquots were checked for feldspar contamination using infrared stimulation. The preheat temperatures and specific details of each study case are in the following sections. Equivalent doses for age calculation were determined with the central age model (CAM) or minimum age model (MAM) (Galbraith et al. 1999). The finite mixture age model (FMM) was used for the single grain data of the Parnaíba River sediments (Galbraith 2005).

For radiation dose rate measurements, sediment samples were packed in sealed plastic containers and stored for at least 28 days, to restore the equilibrium of radon with its daughters. Natural radionuclides concentrations were measured through gamma ray spectrometry in a high purity germanium detector (HPGe, relative efficiency of 55\%) mounted in an ultralow background shield (Canberra Instruments). Uranium thorium and potassium concentrations were converted to dose rates using factors proposed by Adamiec and
Aitken (1998). The contribution of cosmic radiation to the dose rate was calculated according to Prescott and Hutton (1994). Water saturation measured at the time of sampling was used for dose rate corrections.

\section{Late Holocene coastal dune sands from São Francisco do Sul barrier}

OSL dating has been successfully used in highly dynamic coastal systems as a means to study geomorphological evolution, sedimentation rates and the impact of environmental changes (e.g. Bailiff et al. 2014, Ballarini et al. 2003, Rink \& López 2010). Absolute ages ranging from few tens to hundreds of years obtained on beach deposits (Banerjee et al. 2001, Ballarini et al. 2003) to hundreds of thousands of years on stranded coastal barriers (Banerjee et al. 2003) have been reported in numerous studies in coastal settings where other independent chronological controls may not be considered an alternative method. The application of ${ }^{14} \mathrm{C}$, for instance, is usually hindered by the lack of organic materials in coastal sands or by the dating limitation for samples in the decadal timescale because of past fluctuations in the production rate of ${ }^{14} \mathrm{C}$ in the atmosphere (Stuiver 1978). Eolian coastal sediments, in particular, have been ideally suited for OSL dating of quartz. Eolian processes are characterized by a long time of light exposure during sediment transport that promotes well bleached sediments, prior to burial. In Brazil, several authors have reported OSL ages from eolian coastal sediments (Giannini et al. 2007, Sawakuchi et al. 2008, Guedes et al. 2011).

OSL ages in the sands from the São Francisco do Sul Island (SFS; Fig. 4) in connection to geomorphological and sedimentological analyses were decisive in assessing barrier progradation stages from the Mid- to Late-Holocene and appraising the role of sea-level and paleoclimate forcings (Zular et al. 2012). OSL dating on quartz grains were performed following the SAR protocol (Tab. 1), with a preheat temperature of $220^{\circ} \mathrm{C}$ (step 2). Quartz aliquots were characterized by a bright and dominated fast component OSL signal (Fig. 5A), allowing us to measure equivalent dose as low as few tenths of Gy. The dose response curve followed a linear trend for doses up to $1.5 \mathrm{~Gy}$ (Fig. 5B). The quartz responded well to the dose recovery and recycling ratio tests. The equivalent dose distribution for 24 aliquots of sample SFS-18L gave an equivalent dose of $0.0768 \pm 0.0036 \mathrm{~Gy}$, with a $3.1 \%$ overdispersion. The overdispersion measures the variation of equivalent doses among single aliquots or single grains of the same sample. According to Arnold and Roberts (2009), well bleached sediments can present overdispersion up to $35.0 \%$. For sample SFS-18L, it indicates that this is a well bleached sediment, with the absence of post-depositional mixing. All these characteristics attest 
to a reliable OSL age. With an environmental dose rate of $0.880 \pm 0.060 \mathrm{~Gy} / \mathrm{ka}$, the calculated burial age was $87 \pm$ 6 years for sample SFS-L1 8 retrieved at $1.05-\mathrm{m}$ depth in an eolian blowout. The OSL characteristics of quartz from the SFS coast are suitable to measure equivalent doses as low as tenth of Gy, allowing us to determine burial ages of a few decade, possibly even less, all with a $5-10 \%$ uncertainty. This would enable the reconstruction of decadal depositional events on a decadal timescale.

\section{Fluvial sediments from the Pantanal wetland}

The Pantanal is a tectonically active sedimentary basin located in central-west Brazil. The modern landscape comprises a mosaic of depositional environments, which reflects heterogeneous systems within a large depositional tract dominated by alluvial sedimentation (Assine 2003, Assine et al. 2015). The sediment source area originate from the upper Paraguay catchment, which comprises dissected sedimentary rocks (Paraná Basin) and metamorphic rocks (Corumbá and Cuiabá groups) (Lacerda Filho et al. 2004), under tropical-savannah (Aw) climate. The Paraguay River floodplain is the trunk system, but most of the depositional tract is composed of fluvial megafans. Pantanal megafans are characterized by Pleistocene fan lobes with braided distributary channels and sinuous active-Holocene channels which form entrenched meander belts and distributary channel-levee ridges in the distal lobes (Assine \& Soares 2004, Assine et al. 2014). The Pleistocene sediments are mainly represented by medium sands with disperse gravels, and calcrete or ferricrete horizons appear as surface alteration features. In contrast, Holocene deposits are dominated by fine sands, silt and mottled clays (Assine \& Soares 2004, Assine et al. 2014, Pupim 2014).

The absolute ages of the megafans sub environments were determined by OSL dating of several units. It was shown that the ages ranged from a few hundred years up to two hundred thousand years (more details in Assine et al. 2014, Pupim 2014). The Pantanal sediments are well suited to quartz OSL dating, yielding relatively bright OSL signals with more than $50 \%$ of the signal being represented by the fast component. The SAR protocol was used to build a dose response curve

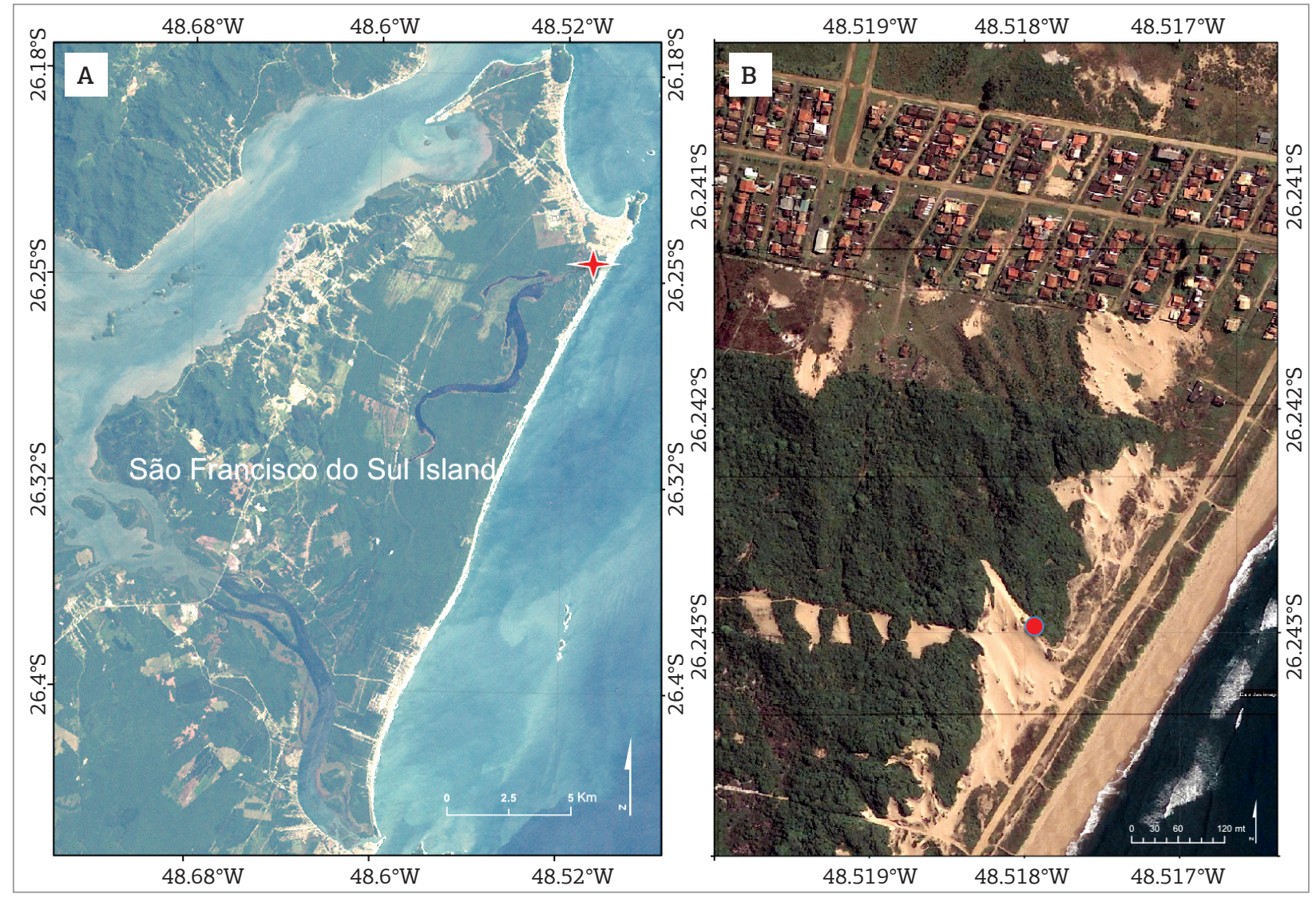

Figure 4. (A) Landsat ETM+7 image (year 2000) of the São Francisco do Sul Island (SFS). (B) The Google Earth image (year 2009) showing a blowout situated at the NE section of the SFS Island. The location is shown by a star in Figure 4(A). The red dot indicates the sampling location for SFS-18L. The initiation of this young blowout in the SFS Island is probably associated with the opening of a crossing unpaved road. 
for quartz aliquots. The dose recovery test using a preheat temperature of $200^{\circ} \mathrm{C}$ performed well, giving a measuredto-given dose ratio of $0.99 \pm 0.01$ (sample SL09) for a given dose of $6.64 \mathrm{~Gy}$. For equivalent dose calculation, we retained only those aliquots that responded well to the recycling ratio (between 0.9 and 1.1) and recuperation test (less than 5\%). The equivalent dose was calculated with the central age model. Two samples collected from deposits of Pleistocene braided channels and Holocene meandering channels gave De values of $9.30 \pm 0.23$ Gy (LC02) and $6.30 \pm 0.15$ Gy (SL09), respectively. The variation in the De values, for both samples, was analyzed to check the possibility of incomplete bleaching, which is considered common in fluvial sediments (e.g. Rittenour 2008). Fortunately here, the studied samples showed equivalent dose distributions with low overdispersion, ranging from 15 to $21 \%$ and suggesting that the luminescence signals in the Pantanal fluvial sediments had been well bleached at deposition. The calculated dose rate of each sample was relatively low, at $0.48 \mathrm{~Gy} / \mathrm{ka}$ (LC02) and $0.58 \mathrm{~Gy} / \mathrm{ka}$ (SL09). The resulted burial ages were $10.7 \pm 1.3 \mathrm{ka}$ (SL09) and $22.2 \pm 2.4 \mathrm{ka}$ (LC02) for samples collected at contrasting fluvial styles (meandering and braided; Pupim 2014). It allowed us to improve our knowledge of fluvial response to environmental changes and anthropogenic disturbances.

\section{Fluvial sediments}

\section{from Parnaíba river basin}

Another example from a fluvial setting is presented here, taken from the Parnaíba and Canindé river terraces, northeastern Brazil. The homogeneity of these samples, in terms of bleaching and/or post-depositional mixing, was investigated, by comparing the equivalent dose distributions obtained from single aliquots and single grains of quartz. The samples were collected in terraces of the Parnaiba River (PNB-17) and its major tributary, the Canindé River (CAN-02) (Fig. 6). The Parnaíba River and its tributaries drain mostly Paleozoic and Mesozoic sedimentary rocks of the Parnaíba sedimentary basin. Their Quaternary terraces generally comprise mature quartz sands with low feldspar content.

The sample PNB-17A was taken in a terrace, situated $10 \mathrm{~m}$ above and at $500 \mathrm{~m}$ away from the modern Parnaíba River channel, in the downstream portion of the catchment. The sample CAN-02A was retrieved in a terrace $5 \mathrm{~m}$ above and $10 \mathrm{~m}$ away from the current Canindé River channel (Fig. 6), in the central portion of the Parnaíba drainage catchment. The sampled sediments are massive sandy beds, with no apparent sedimentary structures, probably due to pedogenetic process. Both rivers are characterized by meandering to straight channels with high suspended load, turbid waters and numerous sand bar tops exposed during the dry season.

The quartz behaved well, having an OSL decay curve dominated by the fast component and well-defined saturating exponential dose response curves. These samples responded well to dose recovery test, both in single aliquot and single grain mode for a preheat temperature of $220^{\circ} \mathrm{C}$. For aliquots, measured-to-given dose ratios were $0.97,0.98$ and 0.92 respectively for given doses of 1.5 and $25 \mathrm{~Gy}$. For single grains, measured-to-given dose ratio was 0.92 for a given

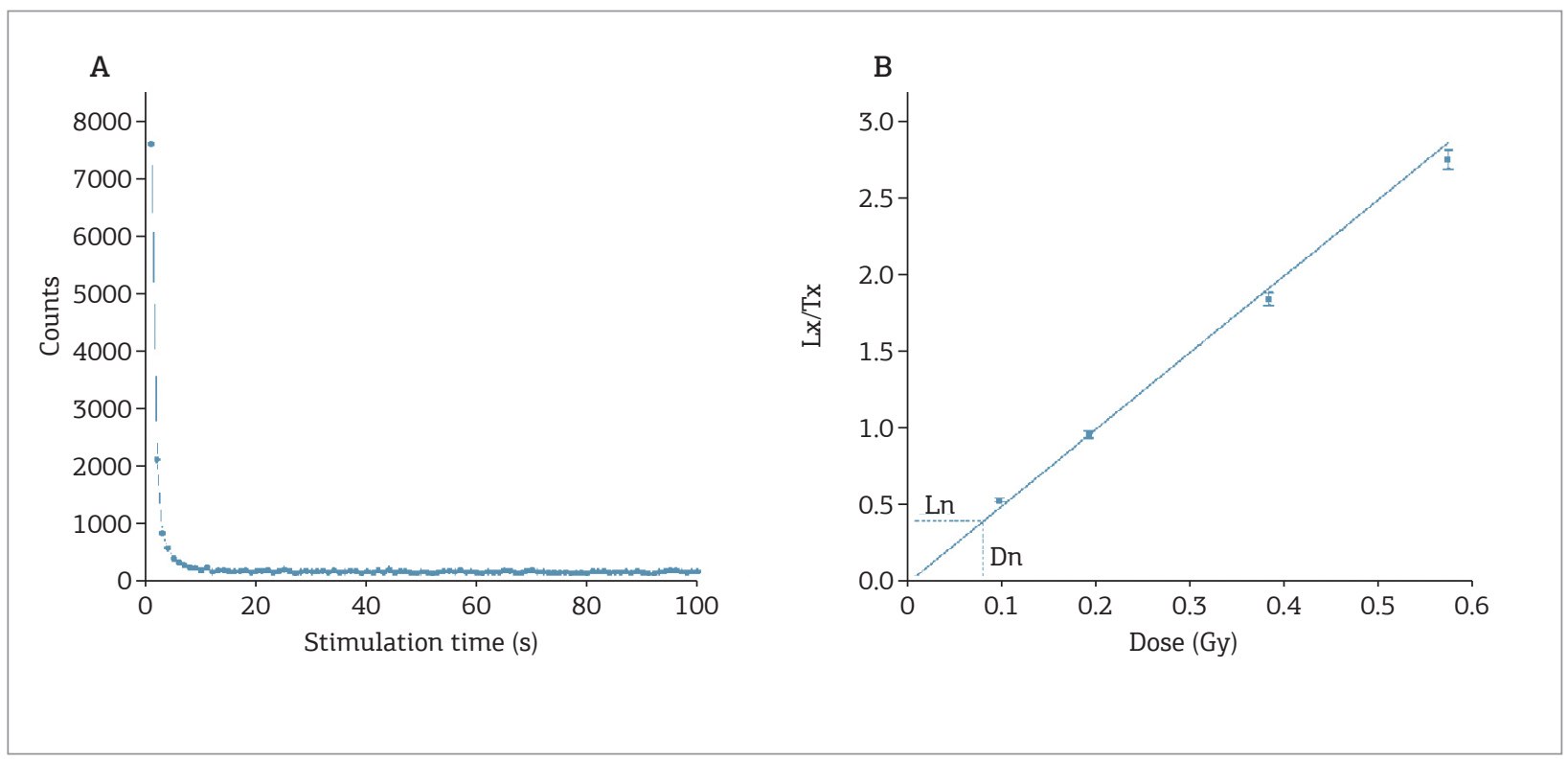

Figure 5. (A) Optically stimulated luminescence decay curve of the natural signal of an aliquot from sample SFS18L. (B) Linear dose response curve for a quartz aliquot from sample SFS-18L. The dashed line represents the interpolation of the natural OSL signal (Ln), giving its natural equivalent dose value (Dn). 
dose of 20 Gy and a preheat temperature of $200^{\circ} \mathrm{C}$. Four hundred grains were measured for each sample. Samples CAN-02A and PNB-17A comprised 6.75 and $14.75 \%$ of the grains with reliable dose response curves. The equivalent dose distributions, from single aliquot measurements, were less scattered compared to single grains results. The Devalues, calculated with the central age model, were 2 and $25 \%$ lower for single grains data of samples CAN-02A and PNB-17A, if compared to those obtained from single aliquots (Fig. 7). The calculated equivalent dose, from sample CAN-02A, gave an overdispersion of 7.8 and $29.9 \%$, for single aliquots and single grains, respectively. A similar situation was observed for sample PNB-17A: the overdispersion was 19.4 or $61.0 \%$ for single aliquots or single grains equivalent doses. The overestimation of equivalent doses using small aliquots is common in fluvial sediments (Thomsen et al. 2007) since there

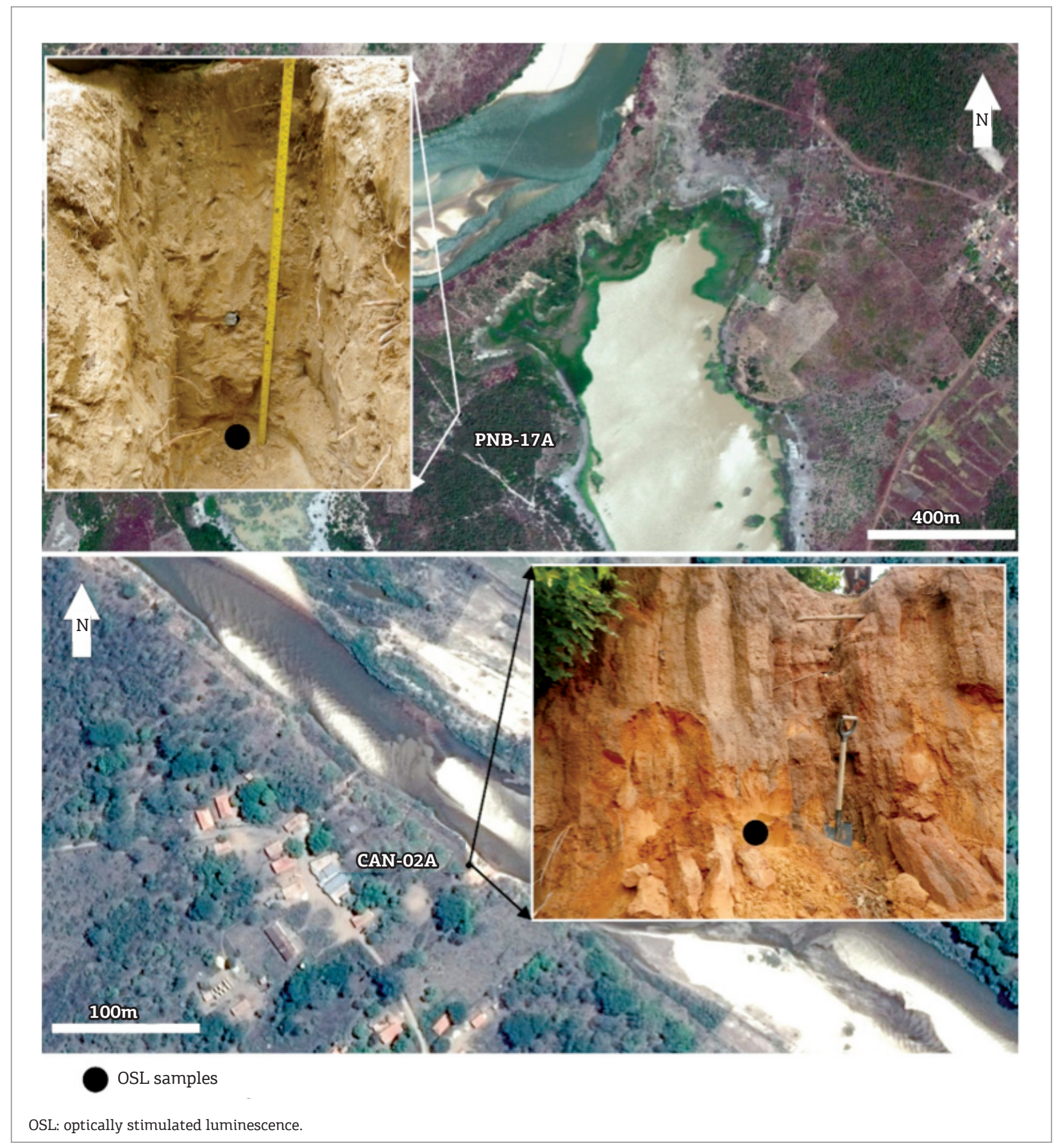

Figure 6. Sediment samples for OSL dating were taken in fluvial terraces of the Parnaíba (PNB-17A) and Canindé (CAN-02A) rivers. Both sites present massive sand beds. 
is a small probability of finding well bleached grains in an aliquot, so the smaller values tend to be averaged.

If every quartz grains, from a sample, are derived from a unique population, their equivalent dose distribution will be normally distributed around the mean. In the case in which the population of quartz grains have different histories, such as in a partially bleached sediment, the equivalent dose distribution will be asymmetric, typically being positively skewed (Rittenour 2008). We can easily imagine that, if many quartz grains are dispensed on aliquot, its equivalent dose will be an average from various population. This will over-estimate the burial age in the case of partial bleaching. By dispensing less and less grains, we can more easily characterize the shape of the distribution. At its limit, we can measure the equivalent dose from a single grain, such as with the single grain laser system. As we reduce the amount of grains underlying the equivalent dose estimate, the equivalent dose distribution will scatter more and more if the quartz grains are derived from more than one population (Duller 2008).
For the samples considered here, the wide scatter observed in the equivalent dose distribution can be attributed to pedogenetic mixing (Fig. 7). The significant degree of pedogenesis is suggested by the lack of sedimentary structures, considering they represent deposition in a fluvial bar. This process seems to be more prevalent in sample PNB-17A. This sample shows an equivalent dose distribution with high dispersion, suggesting two equivalent dose modes.

For sample PNB-17A (Fig. 7), the possibility of post-depositional sediment mixture was evaluated with the MAM and FMM (Galbraith 2005) for comparison with the CAM (Galbraith et al. 1999), since the overdispersion seen in single grain equivalent dose is high. The CAM is suitable to calculate the equivalent dose of a population of well bleached grains without post-depositional mixing. The MAM aims to discriminate a statistic significant number of single aliquots or single grains representing a minimum equivalent dose for calculation of a minimum age. The FFM allows the separation of populations of grains with different depositional histories regarding bleaching or post-depositional

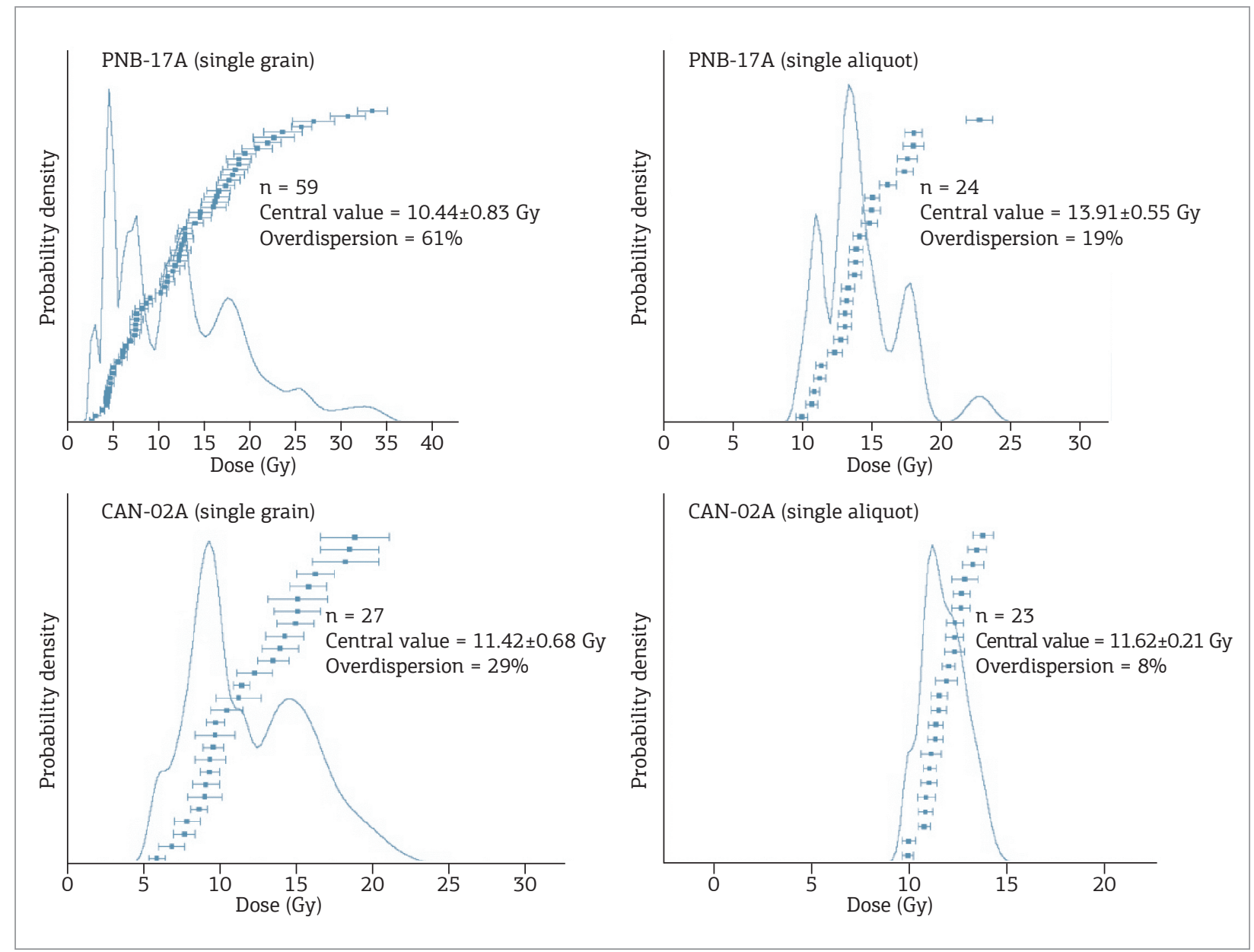

Figure 7. Comparison between equivalent dose distributions in quartz single grains (SG) and single aliquots (SAR) from samples CAN-02A and PNB-17A is shown by probability density plots. 
mixing. Equivalent doses, dose rates and ages for quartz single aliquots and single grains are summarized in Table 2.

The single aliquots ages showed smaller differences between CAM and MAM ages than the single grain ages. In both samples, the younger age corresponds to the single grain MAM age, which is attributed to the separation between well bleached and poorly bleached grains. The minimum age (3.49 $\pm 0.49 \mathrm{ka}$, single grain) and central age model (6.38 $\pm 0.56 \mathrm{ka}$, single aliquot) also gave different results for sample CAN-02A, even if it has a smaller overdispersion compared to sample PNB-17A. Sample PNB-17A shows a higher age range, when the single grain MAM age $(6.25 \pm 0.74 \mathrm{ka})$ and single aliquot age $(18.54 \pm 1.45 \mathrm{ka})$ are compared. Using the FMM, we can reconstruct the observed equivalent doses distribution of sample PNB-17A as resulting from the mixture of two age populations, with equivalent doses of $5.61 \pm 0.08$ Gy and 16.29 $\pm 0.06 \mathrm{~Gy}$, respectively contributing with 40.7 and $59.3 \%$ of the grains from the mixture.

Although poor bleaching in fluvial deposits (Ritennour 2008) is usually considered as a major factor for equivalent dose distributions with high overdispersion, sediment mixture after burial and dose rate heterogeneities can also provoke similar patterns. The field context of the studied samples can help us to interpret the reasons for the high overdispersion observed for sample PNB-17A. This sample was collected in a massive sand layer, most likely due to an intense pedogenesis. The layer above this massive unit (PNB-17B, $30 \mathrm{~cm}$ above) gave a burial age of $9.45 \pm 0.72 \mathrm{ka}$ (CAM). It also has a low overdispersion indicative of a well bleached sediment. This age is close to the younger FMM component seen in sample PNB-17A $(7.48 \pm 0.52 \mathrm{ka})$. In this case, the age of $21.72 \pm 1.47 \mathrm{ka}$ calculated for the older FMM component should be seen as the most reliable age for the bottom sample.

The equivalent dose distribution of sample CAN-02A is relatively symmetric. Therefore, the burial age is most appropriately derived from the CAM. This is supported also in similar weighted mean ages, from single aliquot and single grain data.

Finally, the single grain measurements allow the recognition of sand mixing after burial in sample PNB-17A. Sample CAN-02A is dominated by a well bleached population of grains, without evidence of mixing after burial. Thus, we concluded that contrasting equivalent dose distributions can occur in samples from the same fluvial system and the choice of dating method (aliquots or single grains) and age models should take into account the individual characteristics of each sample.

\section{Carbonate fluvial sediments (tufas) from Serra da Bodoquena and Vale do Ribeira}

Extracting an age from tufa deposits is challenging. The uptake of dead carbon hinders radiocarbon dating while the relatively high concentration of detrital thorium prevents the application of U-Th dating. OSL dating of detrital quartz grains distributed within the tufa matrix is an alternative geochronological method to determine tufa building ages (Rich et al. 2003, Ribeiro et al. 2015). OSL dating was performed in fluvial carbonates from Serra da Bodoquena in Mato Grosso do Sul State and Serra do André Lopes (Vale do Ribeira in São Paulo State) (Fig. 3). The Serra $\mathrm{da}$ Bodoquena is the largest active fluvial tufa depositional system in Brazil. OSL ages shown that these deposits were formed from the Mid-Late Pleistocene to Late Holocene (Ribeiro et al. 2015). The carbonate sediments of Serra da Bodoquena are associated with the karst system developed within Neoproterozoic limestones of Tamengo and Bocaina Formations (Paraguay Belt) that form a plateau over the southern edge of the Pantanal Basin. Tufa deposition occurs when a source of autogenic waters from the karst system emerge in an open-air river, thus supplying bicarbonate-rich waters that rapidly precipitate. The rivers of Serra da Bodoquena

Table 2. Equivalent doses and burial ages, calculated with the central age model, minimum age model and finite mixture model, for single aliquots and single grains from samples CAN-02A and PNB-17A.

\begin{tabular}{|c|c|c|c|c|c|c|c|}
\hline \multirow{2}{*}{ Sample } & \multirow{2}{*}{$\begin{array}{l}\text { Dose rate } \\
\text { (Gy/ka) }\end{array}$} & \multicolumn{3}{|c|}{ Equivalent dose (Gy) } & \multicolumn{3}{|c|}{ Age (ka) } \\
\hline & & CAM & MAM & FMM & CAM & MAM & FMM \\
\hline CAN-02A SG & \multirow{2}{*}{$1.82 \pm 0.16$} & $11.42 \pm 0.68$ & $6.36 \pm 0.70$ & & $6.27 \pm 0.66$ & $3.49 \pm 0.49$ & \\
\hline CAN-02A SA & & $11.62 \pm 0.21$ & $10.48 \pm 0.50$ & & $6.38 \pm 0.56$ & $5.75 \pm 0.57$ & \\
\hline PNB-17A SG & \multirow{2}{*}{$0.75 \pm 0.05$} & $10.44 \pm 0.83$ & $4.69 \pm 0.46$ & & $13.92 \pm 1.45$ & $6.25 \pm 0.74$ & \\
\hline PNB-17A SA & & $13.91 \pm 0.55$ & $9.72 \pm 0.90$ & & $18.54 \pm 1.45$ & $12.96 \pm 1.48$ & \\
\hline PNB-17A Comp.1 (60\%) & \multirow{2}{*}{$0.75 \pm 0.05$} & - & - & $16.29 \pm 0.06$ & - & - & $21.72 \pm 1.47$ \\
\hline PNB-17A Comp.2 (40\%) & & - & - & $5.61 \pm 0.08$ & - & - & $7.48 \pm 0.52$ \\
\hline
\end{tabular}

CAM: central age model; MAM: minimum age model; FMM: finite mixture model; SA: single aliquots; SG: single grains. 
usually have low sinuosity meandering styles and gentle slope forming wide floodplains, accumulating micrite sediment. Barrage-form tufa deposits develop within river channels. Tufa accumulation builds up to form channels with rapids and waterfalls.

The tufa deposits of Serra do André Lopes are associated with the karst developed over the Tapagem Marble, Açungui Suprergroup (Campanha \& Sadowski 1991). The karst system consists mainly of autogenic recharge waters, with a small allogenic recharge originated from topographic highs of non-carbonate rocks (Sallun Filho et al. 2012). The river channels with tufa deposition are developed over a high-gradient area with steep slopes and topographic breaks with narrow and incised river channels.

This study case presents the OSL characteristics and ages of quartz grains retrieved from samples MR-192 (Serra da Bodoquena) and F4-40 (Serra do André Lopes). Ribeiro et al. (2015) give a detailed description of the OSL dating approach for these samples. Both samples are well-cemented, indurated tufas from barrage-type deposits that occur around river channels (Fig. 8). The F4-40 sample has a well-preserved micrite matrix, with coated grains and some sparite cement that fills vuggy pores. The MR-192 sample has a matrix dominated by micro-sparite and sparite. Both samples were collected as blocks knocked from the tufa barrages.

Quartz grains (180 - $250 \mu \mathrm{m}$ fraction) were extracted from the tufa matrix and used for OSL dating. Both samples have quartz grains with OSL signals dominated by the fast component. The quartz from Serra da Bodoquena (MR-192) is brighter than the quartz from Serra do André Lopes (F4-40) (Fig. 3). Recycling ratios are consistent with well-corrected sensitivity changes, and recuperation less than $5.00 \%$ indicates a bleachable OSL signal and absence of significant thermal transfer (Murray \& Wintle 2003). Dose recovery tests show measured-to-given dose ratios of $1.02 \pm 0.09$ (given dose $=33.6 \mathrm{~Gy}$ ) and $0.90 \pm 0.11$ (given dose $=84 \mathrm{~Gy}$ ) for a preheat temperature of $200^{\circ} \mathrm{C}$. The average maximum equivalent doses $\left(2 \mathrm{D}_{0}\right)$ determined using $\mathrm{D}_{0}$ from fitting of dose response curves for samples MR-192 and F4-40 are 97 and 121 Gy, respectively, which are in the range commonly observed for quartz (Wintle 2008). Unfortunately, some aliquots had natural luminescence in dose saturation in both samples. The natural doses determined with the central age model are $70 \pm 5 \mathrm{~Gy}$ (MR-192) and $60 \pm 14$ Gy (F4-40). The studied samples have low concentrations of $\mathrm{U}$, Th and $\mathrm{K}$, giving total dose rates of $0.59 \pm 0.04 \mathrm{~Gy} / \mathrm{ka}$ for sample MR-192 and $0.40 \pm 0.02 \mathrm{~Gy} / \mathrm{ka}$ for sample F4-40. Thus, the OSL ages of the detrital quartz grains within tufa matrix are 118.6 \pm 10.8 and $150.3 \pm 10.8$ ka respectively for samples MR-192 and F4-40.

The studied samples were dated by radiocarbon for comparison with OSL ages (Ribeiro et al. 2015). The radiocarbon age for the carbonate matrix of sample F4-40 is older than 40 - 50 cal ka BP. Sample MR-192 had a radiocarbon age of $0.34-0.51 \mathrm{cal} \mathrm{ka} \mathrm{BP}$ for its carbonate matrix and $7.93-8.02 \mathrm{cal} \mathrm{ka} \mathrm{BP}$ for organic matter within the carbonate matrix (Ribeiro et al. 2015). The equivalent dose distribution for sample MR-192 has a low overdispersion, which suggests a single and uniform distribution. Thus, the younger radiocarbon ages for its carbonate matrix and organic matter could be related to the uptake of modern carbon during tufa dissolution and recrystallization processes. For both samples, the OSL ages would be the most reliable ages for tufa formation, with radiocarbon ages representing younger events of tufa alteration.

Very low water saturation values $(0.2-5.0 \%)$ are observed in the studied tufa samples, which is attributed to the reduced porosity and intense carbonate cementation. This is an important concern for dose rate calculation,
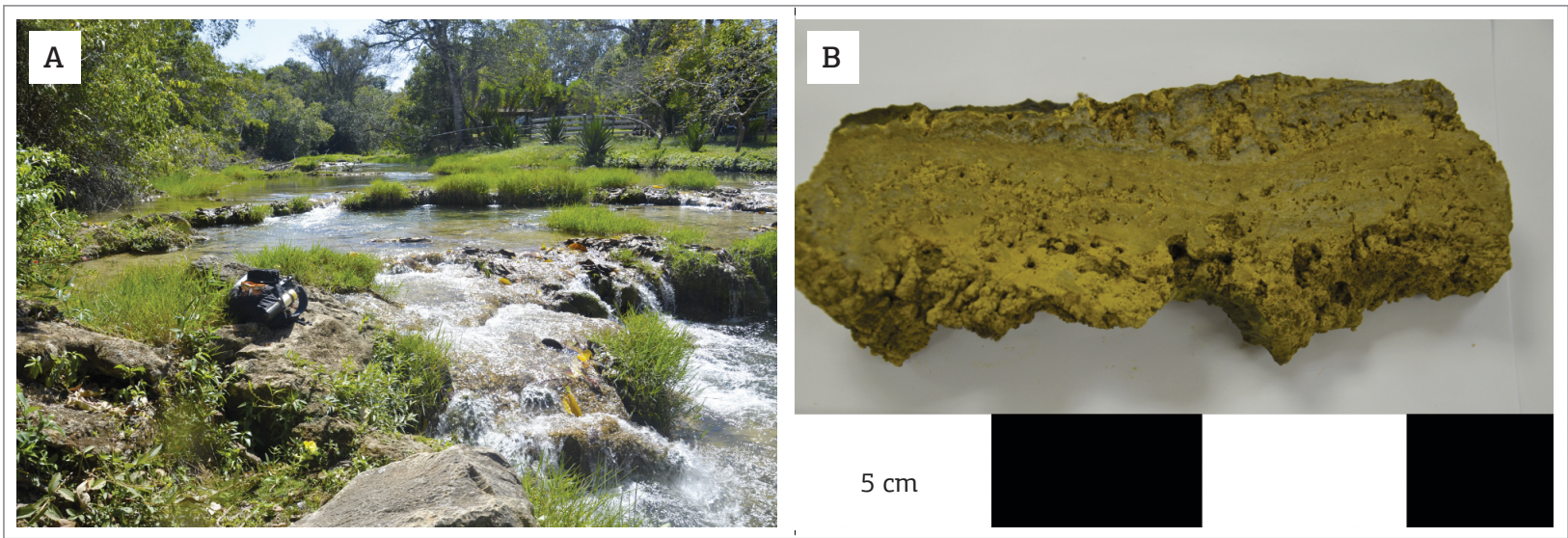

Figure 8. Tufa deposition in fluvial channel (A) and tufa sample (B) from Serra da Bodoquena, southwestern Brazil. 
since the gradual replacement of the available pore space by carbonate cementation progressive increase the dose rate over time. If not taken into account, this leads to an OSL age underestimation. Thus, the studied tufas could be even older. The uptake or loss of radionuclides is another concern for dose rate calculations. The ${ }^{238} \mathrm{U} /{ }^{226} \mathrm{Ra}$ activity ratios are 0.49 (MR-192) and 0.83 (F4-40), indicating an excess of ${ }^{226} \mathrm{Ra}$. The uptake of ${ }^{226} \mathrm{Ra}$ during tufa growth also led to a progressive dose rate increase over time, hence, to an OSL age underestimation if not taken into account. Therefore, the calculated OSL ages should be viewed as minimum age estimates for the formation of the studied tufas.

\section{FEASIBILITY OF USING ISOTHERMAL THERMOLUMINESCENCE SIGNALS TO EXTEND THE AGE LIMIT FOR DATING OF BRAZILIAN SEDIMENTS}

\section{Motivation}

ITL signals of quartz have been shown to saturate at higher doses, compared to OSL, up to $1400 \mathrm{~Gy}$ (Jain et al. 2005). The ITL is the light emitted by a sample heated and kept under a given temperature, without using light stimulation. Quartz ITL signals measured at $310^{\circ} \mathrm{C}$ (Jain et al. 2007) and $270^{\circ} \mathrm{C}$ (Vandenberghe et al. 2009) are thermally stable and bleacheable under sunlight, allowing to extend the age limit of luminescence dating beyond OSL dating of quartz. In a situation in which the environment dose rate is very low, that technique could potentially measure a million year burial age or more. So far, ITL signals were tested for dating of sediments from selected locations in India (Jain et al. 2005), Korea (Choi et al. 2006), China (Buylaert et al. 2006) and Zambia (Barham et al. 2011). Although some studies obtained reliable burial ages (Barham et al. 2011), other studies found systematic ages overestimation (Buylaert et al. 2006, Huot et al. 2006), which was attributed to non-corrected luminescence sensitivity changes. The evaluation of ITL signals in quartz grains from different depositional settings is necessary for the development of a general ITL dating protocol. In this section, we present the first evaluation of ITL signals for dating of Brazilian sediments. ITL measurements to evaluate dose recovery and saturation doses were carried out in quartz from sands of the Xingu River (eastern Amazonia). The quartz from the Xingu River sands has high OSL sensitivity and fast bleaching typical for quartz from most Quaternary depositional settings in Brazil.

\section{Isothermal thermoluminescence measurements}

The sample considered here (XNG-47-2) was collected in a longitudinal bar from the lower reach of the Xingu River (eastern Amazonia, Pará State, northern Brazil). Quartz grains in the $180-250 \mu \mathrm{m}$ grain size were isolated using standard procedures as described in section 3.2. OSL dating using a SAR protocol gave an equivalent dose of $0.31 \pm 0.01$ Gy (24 aliquots and $10 \%$ overdispersion) and a reliable burial age of $205 \pm 5$ years (dose rate of $1.51 \pm$ $0.02 \mathrm{~Gy} / \mathrm{ka}$ ). A dating protocol relying on the ITL $270^{\circ} \mathrm{C}$ (Vandenberghe et al. 2009) and ITL $310^{\circ} \mathrm{C}$ signals (Jain et al. 2007, Barham et al. 2011) was tested for dose recovery tests for a given dose of $250 \mathrm{~Gy}$ (Table 3). The dose recovery tests used aliquots of sample XNG-47-2 (natural dose of $0.31 \pm 0.01 \mathrm{~Gy}$ ) bleached in a solar simulator for 4 hours. Dose response curves were built using radiation doses up to $1200 \mathrm{~Gy}$. The net ITL $270^{\circ} \mathrm{C}$ and ITL $310^{\circ} \mathrm{C}$ signals were calculated by integrating over the first $5 \mathrm{~s}$ of the light emission curve. Background was determined by integrating over the last $40 \mathrm{~s}$.

\section{Results and discussion}

Sample XNG-47-2 shows an ITL $310^{\circ} \mathrm{C}$ signal more intense than the ITL $270^{\circ} \mathrm{C}$ signal. Both signals grow with applied radiation doses and are well represented by a single saturating exponential function (Fig. 9).

The measured-to-given dose was $1.04 \pm 0.21$ ( 4 aliquots) for the ITL $270^{\circ} \mathrm{C}$ and $0.99 \pm 0.19$ ( 3 aliquots) for the ITL $310^{\circ} \mathrm{C}$. Therefore, both signals recovered a reliable given dose of $250 \mathrm{~Gy}$. The natural ITL signals, with both

Table 3. ITL $270^{\circ} \mathrm{C}$ and ITL $310^{\circ} \mathrm{C}$ protocols used for dose recovery test of sample XNG-47-2. Given dose = $250 \mathrm{~Gy}$. Test dose was $62.5 \mathrm{~Gy}$.

\begin{tabular}{c|c|c}
\hline \multirow{2}{*}{ Step } & ITL $270^{\circ} \mathrm{C}$ Protocol & ITL $310^{\circ} \mathrm{C}$ Protocol \\
\cline { 2 - 3 } & Procedure & Procedure \\
\hline 1 & Give dose, $\mathrm{D}_{\mathrm{i}}$ & Give dose, $\mathrm{D}_{\mathrm{i}}$ \\
\hline 2 & Preheat at $300^{\circ} \mathrm{C}$ for $10 \mathrm{~s}$ & Preheat at $260^{\circ} \mathrm{C}$ for $10 \mathrm{~s}$ \\
\hline 3 & ITL at $270^{\circ} \mathrm{C}$ for $600 \mathrm{~s}(\mathrm{Lx})$ & ITL at $310^{\circ} \mathrm{C}$ for $500 \mathrm{~s}(\mathrm{Lx})$ \\
\hline 4 & Test dose, $\mathrm{D}_{\mathrm{t}}$ & Test dose, $\mathrm{D}_{\mathrm{t}}$ \\
\hline 5 & Preheat at $300^{\circ} \mathrm{C}$ for $10 \mathrm{~s}$ & Preheat at $260^{\circ} \mathrm{C}$ for $10 \mathrm{~s}$ \\
\hline 6 & ITL at $270^{\circ} \mathrm{C}$ for $600 \mathrm{~s}(\mathrm{Tx})$ & ITL at $310^{\circ} \mathrm{C}$ for $500 \mathrm{~s}(\mathrm{Tx})$ \\
\hline 7 & $\begin{array}{c}\text { Blue bleach } \\
\text { at } 280^{\circ} \mathrm{C} \text { for } 40 \mathrm{~s}\end{array}$ & $\begin{array}{c}\text { Blue bleach } \\
\text { at } 280^{\circ} \mathrm{C} \text { for } 40 \mathrm{~s}\end{array}$ \\
\hline 8 & Return to step 1 & Return to step 1 \\
\hline
\end{tabular}

ITL: isothermal thermoluminescence. 
approaches, were negligible. It shows that both ITL signals have adequate bleaching characteristics here.

The maximum doses $\left(2 \mathrm{D}_{0}\right)$ calculated using $\mathrm{D}_{0}$ from fitting of a saturating exponential function to the dose response curves are $670 \pm 54 \mathrm{~Gy}$ (average for 4 aliquots) and $1656 \pm 977$ Gy (average for 3 aliquots). These doses are significantly higher than the maximum dose estimated using the blue OSL signal of quartz. The dose rate measured for sample XNG-47-2 is $1.51 \pm 0.02 \mathrm{~Gy} / \mathrm{ka}$, which would allow determining ages up to around $1 \mathrm{Ma}$ using the ITL $310^{\circ} \mathrm{C}$ signal. The dose rate for sample XNG-47-2 is relatively high compared to average dose rates between 0.5 and $1.0 \mathrm{~Gy} / \mathrm{ka}$ commonly found in Brazilian sediments (Sawakuchi et al. 2008, Soares et al. 2010, Guedes et al. 2013, Ribeiro et al. 2015). In this case, burial ages for the whole Quaternary (up to around 2.58 Ma) or even beyond could be determined for some low dose rate $(-0.5 \mathrm{~Gy} / \mathrm{ka})$ Brazilian sediments using ITL signals.

\section{CONCLUDING REMARKS}

Quartz from Quaternary sediments in Brazil is well suited for luminescence dating. They have a bright and proportionally important fast component. The high sensitivity usually found in quartz from Brazilian sediments would allow determining burial ages as young as a few years. Despite the relatively low dose rates usually found for quartz from Brazilian sediments $(0.5-1.5 \mathrm{~Gy} / \mathrm{ka})$, such as that found in the Pantanal wetland and fluvial carbonates from Serra da Bodoquena, saturation doses up to $100-150$ Gy limit the upper dating range of sediments to $300 \mathrm{ka}$.

Fluvial sediments are commonly reported as suffering from incomplete bleaching, which makes difficult to estimate a reliable burial age. However, fluvial sediments from four different settings in Brazil (Pantanal, Parnaíba river, Serra da Bodoquena and Vale do Ribeira) are relatively well bleached with equivalent dose distributions showing low
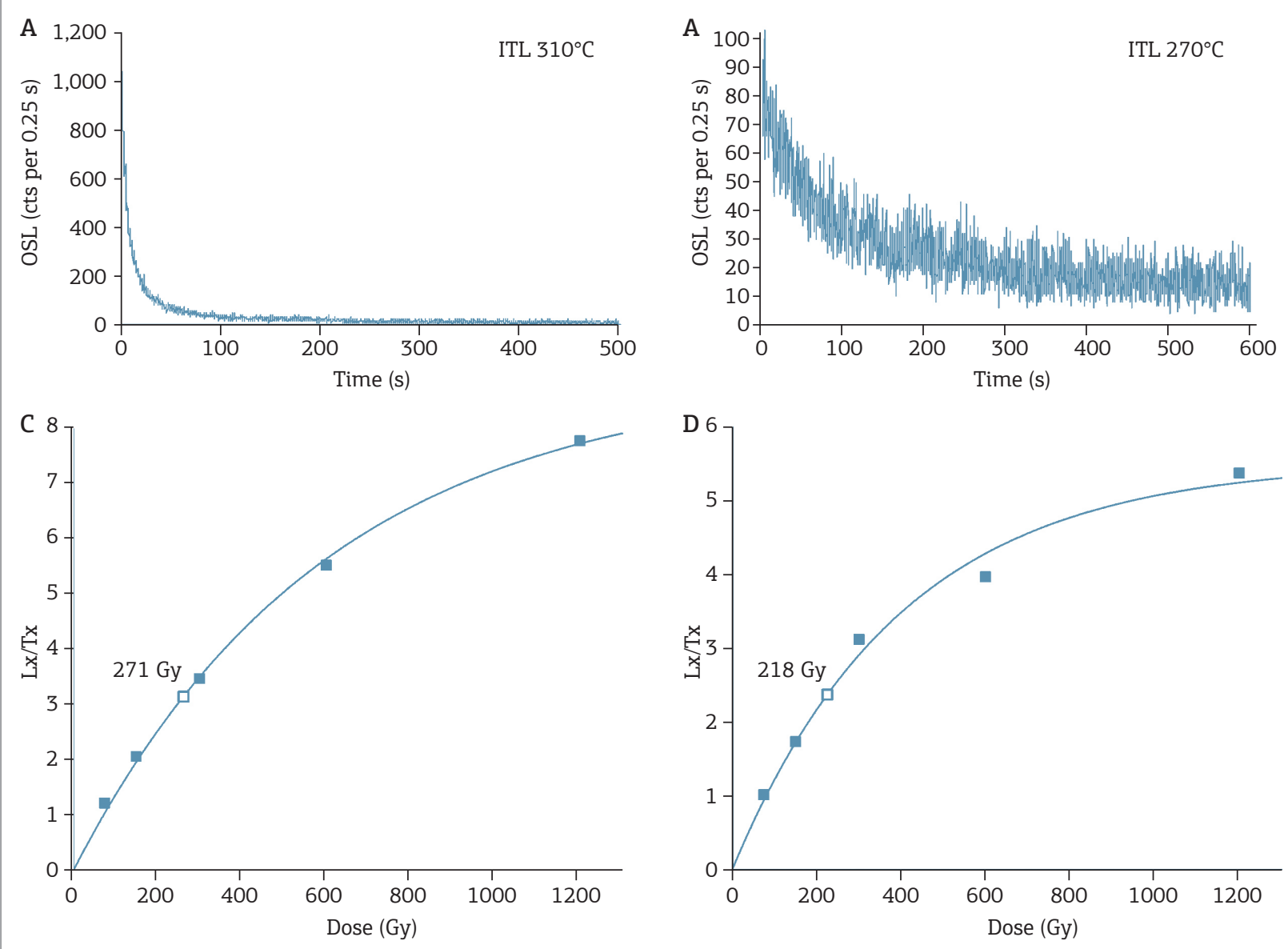

OSL: optically stimulated luminescence; ITL: isothermal thermoluminescence.

Figure 9. Isothermal thermoluminescence decay curves for the natural ITL $310^{\circ} \mathrm{C}(\mathrm{A})$ and ITL $270^{\circ} \mathrm{C}$ (B) signals. The dose response curves of the ITL $310^{\circ} \mathrm{C}$ (C) and ITL $270^{\circ} \mathrm{C}$ (D) are well described by fitting of exponential saturating function. The estimated dose (white square) corresponds to a given dose of $250 \mathrm{~Gy}$. 
to moderate overdispersions, similar to values observed in coastal or eolian sediments. All studied fluvial settings comprise sands with very low feldspar content. The studied fluvial sands are mainly composed (> 90\%) of bright quartz grains dominated by the fast OSL component. This suggests that quartz sensitivity and homogeneity of sand composition play a major role in the overdispersion of equivalent dose distributions. High overdispersion was observed only for fluvial sediments with intense pedogenesis (Parnaíba River). The analysis of single grain data allowed concluding that the higher overdispersion is related to post-depositional mixing rather than insufficient sunlight bleaching. Therefore, sediment mixing due to pedogenesis and dose rate heterogeneities would be the major contributors to high overdispersion in Brazilian fluvial sediments. In this case, selection of sampling sites should avoid these situations.

OSL dating of detrital quartz grains is a promising method to determine deposition ages of carbonate fluvial sediments (tufas), which are still challenging materials for dating using other geochronological methods. Dose rate variation through time due to changes in pore water content and loss or uptake of radionuclides are the main concerns for dating of tufas using OSL methods. Thus, dose rate modeling provoked by changes in radionuclide concentrations and water content is necessary to enhance the dating accuracy.

Most of the Quaternary period is beyond the age limits of the OSL dating. Dating protocols based on ITL signals from quartz are promising methods to extend the age range of luminescence dating. The first ITL measurements performed in quartz from Brazilian sediments (Xingu River) suggest that equivalent doses up to $1600 \mathrm{~Gy}$ (2D0) can be recovered, considering the obtained saturation level of ITL $310^{\circ} \mathrm{C}$ signal. If accurate, we could measure burial ages for most of the Quaternary or even for the Pliocene ( $-3 \mathrm{Ma})$ in low dose rate environments $(0.5 \mathrm{~Gy} / \mathrm{ka})$. Further development is called for to determine the reliability of ITL dating of Brazilian quartz, with a comparison to independent dating methods.

\section{ACKNOWLEDGMENTS}

The authors are thankful to the valuable effort and detailed suggestions and explanations from Sebastien Huot and an anonymous reviewer, which greatly improved the paper. São Paulo Research Foundation (FAPESP) is acknowledged for funding (grant 2009/53988-8) the installation of the Luminescence and Gamma Spectrometry Laboratory at the Institute of Geosciences of the Universidade de São Paulo.

WSF and LMAR thank FAPESP (grant 2014/14433-9) for funding the study of tufas from Serra da Bodoquena. VRM thanks FAPESP (grant 2013/21942-4) for funding the PhD scholarship MLA thanks FAPESP (grant 2014/06889-2) for funding the research of Pantanal dynamic. FNP thanks FAPESP (grant 2014/23334-4) for funding the Postdoctoral scholarship.

\section{REFERENCES}

Adamiec G. \& Aitken M. 1998. Dose-rate conversion factors: update. Ancient TL, 16(2):37-50.

Aitken M.J. 1998. An Introduction to Optical Dating. London: Oxford University Press, $267 \mathrm{p}$

Aitken M.J., Tite M.S., Reid J. 1964. Thermoluminescent dating of ancient ceramics. Nature, 202:1032-1033.

Araujo A.G.M., Feathers J.K., Arroyo-Kalin M., Tizuka M.M. 2008. Lapa das Boleiras rockshelter: stratigraphy and formation processes at a paleoamerican site in Central Brazil. Journal of Archaeological Science, 25:3186-3202.

Arnold L.J. \& Roberts R.G. 2009. Stochastic modeling of multi-grain equivalent dose $\left(D^{\mathrm{e}}\right)$ distributions: implications for OSL dating of sediment mixtures. Quaternary Research, 55:159-167.

Assine M.L. 2003. Sedimentação na Bacia do Pantanal MatoGrossense, Centro-Oeste do Brasil. Tese de Livre-Docência, Instituto de Geociências e Ciências Exatas, Universidade Estadual Paulista UNESP, Rio Claro, 106p.

Assine M.L. \& Soares P.C. 2004. Quaternary of the Pantanal, westcentral Brazil. Quaternary International, 114:23-34.

Assine M.L., Corradini F.A., Pupim F.N., McGlue M.M. 2014. Channel arrangements and depositional styles in the São Lourenço fluvial megafan, Brazilian Pantanal wetland. Sedimentary Geology, 301:172-184.
Assine, M.L., Merino, E.R., Pupim, F.N., Macedo, H.A., Santos, M.G. 2015. The Quaternary alluvial systems tract of the Pantanal Basin, Brazil. Brazilian Journal of Geology, 45(3):475-489.

Bailey R.M, Smith B.W., Rhodes E.J. 1997. Partial bleaching and the decay form characteristics of quartz OSL. Radiation Measurements, 27:123-136.

Bailiff I.K., French C.A., Scarre C.J. 2014. Application of luminescence dating and geomorphological analysis to the study of landscape evolution, settlement and climate change on the Channel Island of Herm. Journal of Archaeological Science, 41:890-903.

Ballarini M., Wallinga J., Murray A.S., Van Heteren S., Oost A.P., Bos A.J.J., Van Eijk C.W.E. 2003. Optical dating of young coastal dunes on a decadal time scale. Quaternary Science Reviews, 22:1011-1017.

Banerjee D., Hildebrand A.N., Murray-Wallace C.V., Bourman R.P., Brooke B P., Blair M. 2003. New quartz SAR-OSL ages from the stranded beach dune sequence in south-east South Australia. Quaternary Science Reviews, 22:1019-1025.

Banerjee, D., Murray, A.S., Foster, I.D.L., 2001. Scilly isles, UK: optical dating of a possible tsunami deposit from the 1755 Lisbon earthquake. Quaternary Science Reviews, 20:715-718.

Barham L., Phillips W.M., Maher B.A., Karloukovski V., Duller G.A., Jain M., Wintle A.G. 2011. The dating and interpretation of a Mode 1 site in the Luangwa Valley, Zambia. Journal of human evolution, 60(5):549-570. 
Barreto A.M.F., Suguio K., Tatumi S.H., Yee M., Giannini P.C.F., Bezerra F.H.R. 2001. Dunas inativas do Rio Grande do Norte: idades, áreasfonte e possíveis correspondências com o nível relativo do mar no Quaternário. In: Simpósio Regional de Geologia do Nordeste. Boletim de Resumos... Recife, SBG.

Barreto A.M.F., Suguio K., Bezerra F.H.R., Tatumi S.H., Giannini P.C.F. 2004. Geologia e geomorfologia do Quaternário costeiro do Estado do Rio Grande do Norte. São Paulo, Geologia-USP - Série Científica, 4(2):1-12.

Bueno L., Feathers J., De Blasis P. 2012. The formation process of a paleoindian open-air site in Central Brazil: integrating lithic analysis, radiocarbon and luminescence dating. Journal of Archaeological Science, 40:190-203.

Buylaert J.P., Murray A.S., Huot S., Vriend M.G.A., Vandenberghe D., De Corte F., Van Den Haute P. 2006. A comparison of quartz OSL and isothermal TL measurements on Chinese loess. Radiation Protection Dosimetry, 119:474-478

Buylaert J.P., Jain M., Murray A.S., Thomsen K.J., Thiel C., Sohbati R. 2012. A robust feldspar luminescence dating method for Middle and Late Pleistocene sediments. Boreas, 41(3):435-451.

Campanha G.A.C. \& Sadowski G.R. 1999. Tectonics of the southem portion of the Ribeira Belt (Apiaí Domain). Precambrian Research, 98:31-51.

Choi J.H., Murray A.S., Cheong C.S., Hong D.G., Chang H.W. 2006. Estimation of equivalent dose using quartz isothermal TL and the SAR procedure. Quaternary Geochronology, 1(2):101-108.

Duller G.A.T. 2008. Single-grain optical dating of Quaternary sediments: why aliquot size matters in luminescence dating. Boreas, 37(4):589-612.

Duller G.A.T. \& Wintle A.G. 2012. A review of the thermally transferred optically stimulated luminescence signal from quartz for dating sediments. Quaternary Geochronology, 7:6-20.

Feathers J., Kupnis R., Piló L., Arroyo-Kalin M., Coblentz D. 2010. How old is Luzia? Luminescence dating and stratigraphic integrity at Lapa Vermelha, Lagoa Santa, Brazil. Geoarchaeology, 1:395-436.

Galbraith R.F. 2005. Statistics for Fission Track Analysis. Boca Raton: Interdisciplinary Statistics, Chapman and Hall.

Galbraith R.F., Roberts R.G., Laslett G.M., Yoshida H., Olley J.M. 1999. Optical dating of single and multiple grains of quartz from Jinmium rock shelter, northern Australia: Part I, Experimental desing and statistical models. Archaeometry, 41:361-364.

Giannini P.C.F., Sawakuchi A.O., Martinho C.T., Tatumi S.H. 2007. Eolian depositional episodes controlled by Late Quaternary relative sea level changes on the Imbituba-Laguna coast (southern Brazil). Marine Geology 237:143-168.

Giannini P.C.F, Guedes C.C.F., Nascimento Jr. D.R., Tanaka A.P.B., Angulo R.J., Assine M.L., Souza M.C. 2009. Sedimentology and morphologic evolution of the Ilha Comprida Barrier system, southern São Paulo coast. In: Dillenburg S.R. and Hesp P. (Eds). Geology of the Brazilian coastal barriers: Lecture Notes in Earth Sciences. Springer-Verlag.

Giannini P.C.F, Villagran X.S., Fornari M., Nascimento Jr. D.R., Menezes P.M.L., Tanaka A.P.B. Assunção, D.C., De Blasis P., Amaral P.G.C. 2010. Interações entre evolução sedimentar e ocupação humana na costa centro-sul de Santa Catarina, Brasil. Boletim do Museu Paraense Emílio Goeldi, Ciências Humanas, 5(1):105-128.

Godfrey-Smith D.I., Huntley D.J., Chen W.H. 1988. Optical dating studies of quartz and feldspar sediment extracts. Quaternary Science Reviews, 7(3):373-380.

Guedes C.C.F., Giannini P.C.F., Sawakuchi A.O., DeWitt R., Nascimento Jr. D.R., Aguiar V.A.P., Rossi M.G. 2011. Determination of controls on Holocene barrier progradation through application of OSL dating: the Ilha Comprida Barrier example, Southeastern Brazil. Marine Geology, 285:11-16.
Guedes C.C.F. Sawakuchi A.O., Giannini P.C.F., DeWitt R., Aguiar V.A.P. 2013. Luminescence characteristics of quartz from Brazilian sediments and constraints for OSL dating. Anais da Academia Brasileira de Ciências, 85:1303-1316.

Guérin G., Mercier N., Adamiec G. 2011. Dose-rate conversion factors: update. Ancient TL, 29(1):5-8.

Huntley D.J., Godfrey-Smith D.I., Thewalt M.L.W. 1985. Optical dating of sediments. Nature, 313:105-107.

Huntley D.J. \& Lamothe M. 2001. Ubiquity of anomalous fading in $\mathrm{K}$-feldspars and the measurement and correction for it in optical dating. Canadian Journal of Earth Sciences, 38(7):1093-1106.

HuotS.,BuylaertJ.P., Murray A.S.2006. Isothermal thermoluminescence signals from quartz. Radiation Measurements, 41:796-802.

Jain M., Bøtter-Jensen L., Murray A.S., Denby P.M., Tsukamoto S., Gibling M.R. 2005. Revisiting TL: dose measurement beyond the OSL range using SAR. Ancient TL, 23:9-24.

Jain M., Duller G.A.T., Wintle A.G. 2007. Dose response, thermal stability and optical bleaching of the $310^{\circ} \mathrm{C}$ isothermal TL signal in quartz. Radiation Measurements, 42:1285-1293.

Johnson N.M. 1963. Thermoluminescence in contact metamorphosed limestone. Journal of Geology, 71:596-616.

Johnson N.M. 1966. Determination of magma temperatures from natural thermoluminescence. In: Thermoluminescence of geological materials. NATO Advanced Research Inst., Spoleto, p. 545-546.

Lacerda Filho J.V. 2004. Geologia e Recursos Minerais do Estado de Mato Grosso. In: Lacerda Filho J.V., Abreu Filho W., Valente C.R., Oliveira C.C., Albuquerque M.C. (Org.) Esc. 1:1.000.000. Goiânia: CPRM, 2004. (Convênio CPRM/SICME): 200 il.; + mapas.

Macdiarmid R.A. 1963. The application of thermoluminescence to geothermometry. Economic Geology, 58:1218-1228.

Mauz B., Packman S., Lang A. 2006. The alpha effectiveness in siltsized quartz: New data obtained by single and multiple aliquot protocols. Ancient TL, 24(2):47-52.

Mendes V.R., Giannini P.C.F., Guedes C.C.F., DeWitt R., De Abreu Andrade H.A.A. 2015. Central Santa Catarina coastal dunefields chronology and their relation to relative sea level and climatic changes. Brazilian Journal of Geology, 45:79-95.

Murray A.S., Wintle A.G. 1998. Factors controlling the shape of the OSL decay curve in quartz. Radiation Measurements, 29:65-79.

Murray A. \& Wintle A.G. 2000. Luminescence dating of quartz using an improved single-aliquot regenerative-dose protocol. Radiation Measurements, 32:57-73.

Murray A.S. \& Wintle A.G. 2003. The single aliquot regenerative dose protocol: potential for improvements in reliability. Radiation Measurements 37:377-381

Poupeau G., Soliani Junior E.L., Rivera A., Loss E.L., Vasconcellos M.B.A. 1988. Datação por termoluminescência de alguns depósitos arenosos costeiros, do Último Ciclo Climático, no nordeste do Rio Grande do Sul. Pesquisas, 21:25-47.

Poupeau G., Souza J.H., Soliani Junior E.L., Loss E.L. 1984. Dating quartzose sands of the Coastal Province of Rio Grande do Sul, Brazil, by thermoluminescence. Pesquisas, 16:250-268.

Prescott, J.R. \& Hutton, J.T. 1994. Cosmic ray contributions to dose rates for luminescence and ESR dating: Large depths and longterm time variations. Radiation Measurements, 23(2-3):497-500.

Pupim F.N. 2014. Geomorfologia e paleo-hidrologia dos megaleques dos rios Cuiabá e São Lourenço, Quaternário da Bacia do Pantanal. Tese de Doutorado, Instituto de Geociências e Ciências Exatas, Universidade Estadual Paulista - UNESP, Rio Claro, São Paulo, 109 p. 
Rhodes E.J. 2011. Optically Stimulated Luminescence Dating of Sediments over the Past 200,000 Years. Annual Review of Earth and Planetary Sciences, 39(1):461-488.

Ribeiro L.M.A.L., Sawakuchi A.O., Wang H., Sallun Filho W., Nogueira L. 2015. OSL dating of Brazilian fluvial carbonates (tufas) using detrital quartz grains. Quaternary International, 362:146-156.

Rich J., Stokes S., Wood W., Bailey R. 2003. Optical dating of tufa via in situ Aeolian sand grains: a case example from the Southern High Plains, USA. Quaternary Science Reviews, 22:1145-1152.

Rink W.J. \& López G.I. 2010. OSL-based lateral progradation and aeolian sediment accumulation rates for the Apalachicola Barrier Island Complex, North Gulf of Mexico, Florida. Geomorphology, 123:330-342.

Rittenour T.M. 2008. Luminescence dating of fluvial deposits: applications to geomorphic, palaeoseismic and archaeological research. Boreas, 37:613-635.

Sallun A.E.M., Suguio K., Tatumi S.H., Yee M., Santos J., Barreto A.M.F. 2007. Datação absoluta de depósitos quaternários brasileiros por luminescência. Revista Brasileira de Geociências, 37(2):402-413.

Sallun A.E.M. \& Suguio K. 2010. Quaternary colluvial episodes (upper Paraná river hydrographic basin, Brazil). Anais da Academia Brasileira de Ciências, 82(3):701-715.

Sallun Filho W., Almeida L.H.S., Boggiani P.C., Karmann I. 2012. Characterization of quaternary tufas in the Serra do André Lopes karst, southeastern Brazil. Carbonates and Evaporites, 27:357-373.

Sawakuchi A.O., Kalchgruber R., Giannini P.C.F., Nascimento Jr. D.R., Guedes C.C.F., Umisedo N.K. 2008. The development of blowouts and foredunes in the Ilha Comprida barrier (Southeastern Brazil): the influence of Late Holocene climate changes on coastal sedimentation. Quaternary Science Reviews, 27:2076-2090.

Sawakuchi A.O., Blair M.W., DeWitt R., Faleiros F.M., Hyppolito T., Guedes C.C.F. 2011. Thermal history versus sedimentary history: OSL sensitivity of quartz grains extracted from rocks and sediments. Quaternary Geochronology, 6:261-272.

Soares E.A.A., Tatumi S.H., Riccomini C. 2010. OSL age determination of Pleistocene fluvial deposits in Central Amazonia. Anais da Academia Brasileira de Ciências, 82:691-699.

Stuiver M. 1978. Radiocarbon timescale tested against magnetic and other dating methods. Nature, 273:271-274.

Suguio K., Tatumi S.H., Kowata E.A. 1999. The Comprida Island inactive dune ridges and their possible significance for the island evolution during the Holocene, State of São Paulo, Brazil. Anais da Academia Brasileira de Ciências, 71:623-630.
Suguio K., Tatumi S.H., Kowata E.A., Munita C.S., Paiva R.P. 2003. Upper Pleistocene deposits of the Comprida Island (São Paulo State) dated by thermoluminescence method. Anais da Academia Brasileira de Ciências, 75:91-96.

Tatumi S.H., Silva L.P., Pires E.L., Rossetti D.F., Góes A.M., Munita C. 2008. Datação de sedimentos Pós-Barreiras no norte do Brasil: implicações paleogeográficas. Revista Brasileira de Geociências, 38(3):514-524

Teeuw M.R. \& Rhodes E.J. 2004. Aeolian activity in northern Amazonia: optical dating of Late Pleistocene and Holocene palaeodunes. Journal of Quaternary Science, 19:49-54.

Thomsen K.J., Murray A.S., Bøtter-Jensen L., Kinahan, J. 2007. Determination of burial dose in incompletely bleached fluvial samples using single grains of quartz. Radiation Measurements, 42:370-379.

Thomsen K.J., Murray A.S., Jain M., Bøtter-Jensen L. 2008. Laboratory fading rates of various luminescence signals from feldspar-rich sediment extracts Radiation Measurements, 43:1474-1486.

Tsoar H., Levin N., Porat N., Maia L.P., Herrmann H.J., Tatumi S.H., Claudino-Sales V. 2009. The effect of climate change on the mobility and stability of coastal sand dunes in Ceará State (NE Brazil). Quaternary Research, 71:217-226.

Vandenberghe D.A.G., Jain M., Murray A.S. 2009. Equivalent dose determination using a quartz isothermal TL signal. Radiation Measurements, 44(5-6):439-444.

Wang X.L., Wintle A.G., Lu Y.C., 2006. Thermally-transferred luminescence in fine-grained quartz from Chinese loess: basic observations. Radiation Measurements, 41:649-658.

Wintle A.G. 2008. Luminescence dating: where it has been and where it is going. Boreas, 37:471-482.

Wintle A.G. \& Murray A.S. 2006. A review of quartz optically stimulated luminescence characteristics and their relevance in single-aliquot regeneration dating protocols. Radiation Measurements, 41:369-391.

Yukihara E.G. \& McKeever S.W.S. 2011. Optically stimulated luminescence-Fundamentals and applications. John Wiley \& Sons, Oklahoma.

Zular A., Sawakuchi A.O., Guedes C.C.F., Mendes V.R., Nascimento Jr. D.R., Giannini P.C.F., Aguiar V.A.P., DeWitt R. 2012. Late Holocene intensification of colds fronts in southern Brazil as indicated by dune development and provenance changes in the São Francisco do Sul coastal barrier. Marine Geology, 335:64-77.

Available at www.sbgeo.org.br 